\title{
Thioureido Cymantrene Derivatives: Synthesis and Photochromic Properties
}

Elena S. Kelbysheva*[a], Lyudmila N. Telegina ${ }^{[a]}$, Tatyana V. Strelkova ${ }^{[a]}$, Mariam G. Ezernitskaya $^{[\mathrm{a}]}$, Aleksander F. Smol'yakov ${ }^{[\mathrm{a}, \mathrm{b}]}$, Yurii A. Borisov ${ }^{[\mathrm{a}]}$, Boris V. Lokshin ${ }^{[\mathrm{a}]}$, Elizaveta A. Konstantinova ${ }^{[\mathrm{c}]}$, Oleg I. Gromov ${ }^{[\mathrm{d}]}$, Alexander I. Kokorin ${ }^{[\mathrm{e}]}$ and Nikolay M. Loim ${ }^{[\mathrm{a}]}$

\footnotetext{
${ }^{a} A$. N. Nesmeyanov Institute of Organoelement Compounds, Russian Academy of Sciences, 28 Vavilov street, GSP1, Moscow, 119991, Russian Federation.

bPlekhanov Russian University of Economics, Stremyanny per. 36, Moscow, 117997, Russian Federation

'National Research Center 'Kurchatov Institute', Akademika Kurchatova 1, Moscow, 123182, Russian Federation.

${ }^{d}$ Chemistry Department, M. V. Lomonosov Moscow State University, Leninskie Gory 1-2, Moscow, 119991, Russian Federation.

${ }^{\mathrm{e} N}$. N. Semenov Institute of Chemical Physics RAS, Kosygin st. 4, Moscow, 119991, Russian Federation.
}

Supporting Information

\section{Table of Contents}

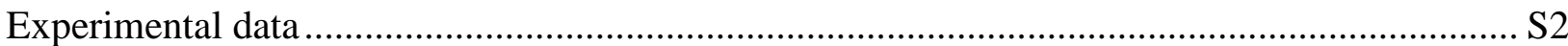

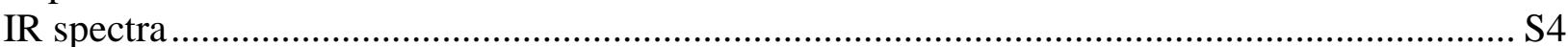

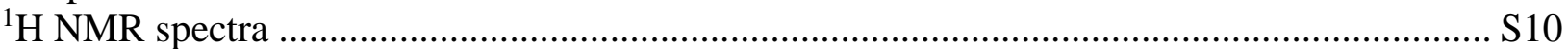

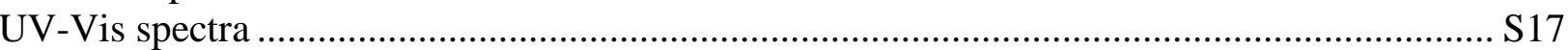

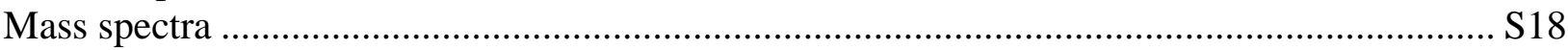

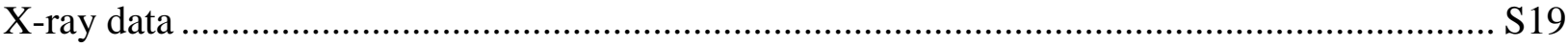

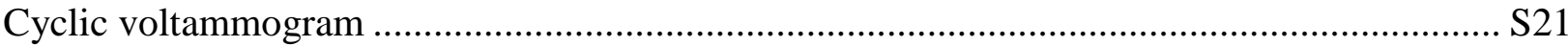

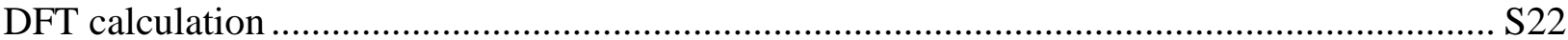




\section{Experimental data}

Table S1. Experimental data on the IR and UV-Vis spectra of compounds 4-12, 16, 17 and 1921 and kinetic data of compound 7-9, 16, 17 and 20.

\begin{tabular}{|c|c|c|c|c|}
\hline Compound & $\mathrm{IR}, \mathrm{cm}^{-1}$ & $\lambda, \mathrm{nm}(\varepsilon)$ & $\mathrm{t}_{1 / 2,2}, \min$ & $\mathrm{k}_{\mathrm{obs}} * 10^{4}, \mathrm{sec}^{-1}$ \\
\hline 4 & $\begin{array}{l}2019,1938^{\mathrm{a}} \\
2020,1936^{\mathrm{b}} \\
2020,1933^{\mathrm{c}}\end{array}$ & $\begin{array}{l}323(1766)^{\mathrm{a}} \\
324(1654)^{\mathrm{b}}\end{array}$ & & \\
\hline 7 & $\begin{array}{l}1927,1863^{\mathrm{a}} \\
1920,1853^{\mathrm{b}} \\
1917,1846^{\mathrm{c}}\end{array}$ & $\begin{array}{l}403(958), 508 \\
(877)^{\mathrm{a}} \\
394(642), 494 \\
(584)^{\mathrm{b}}\end{array}$ & $697^{\mathrm{a}}$ & $0.17 \pm 0.003^{\mathrm{a}}$ \\
\hline 10 & $\begin{array}{l}2005,1936^{\mathrm{a}} \\
2004,1933^{\mathrm{b}} \\
2004,1936^{\mathrm{c}}\end{array}$ & $\begin{array}{l}503(2272), 629 \\
(867)^{\mathrm{a}} \\
492(917), 616 \\
(122)^{\mathrm{b}}\end{array}$ & & \\
\hline 5 & $\begin{array}{l}2022,1937^{\mathrm{a}} \\
2021,1936^{\mathrm{b}}\end{array}$ & $334(1177)^{\mathrm{a}}$ & & \\
\hline 8 & $\begin{array}{l}1927,1862^{\mathrm{a}} \\
1921,1855^{\mathrm{b}}\end{array}$ & $\begin{array}{l}390(1082), 495 \\
(479)^{\mathrm{a}} \\
418(1242), 502 \\
(994)^{\mathrm{b}}\end{array}$ & $48^{\mathrm{a}}$ & $1.94 \pm 0.018^{a}$ \\
\hline 11 & $\begin{array}{l}2002,1934^{\mathrm{a}} \\
2004,1933^{\mathrm{b}}\end{array}$ & $\begin{array}{l}502(607), 605 \\
(107)^{\mathrm{a}} \\
496(1078), 590 \\
(509)^{\mathrm{b}}\end{array}$ & & \\
\hline 16 & $\begin{array}{l}1967,1905^{\mathrm{a}} \\
1965,1902^{\mathrm{b}}\end{array}$ & $\begin{array}{l}329(3586)^{\mathrm{a}} \\
321(1661)^{\mathrm{b}}\end{array}$ & $248^{\mathrm{a}}$ & $0.52 \pm 0.006^{\mathrm{a}}$ \\
\hline 6 & $\begin{array}{l}2020,1935^{\mathrm{a}} \\
2019,1934^{\mathrm{b}} \\
2020,1932^{\mathrm{c}}\end{array}$ & $\begin{array}{l}332(1594)^{\mathrm{a}} \\
332(2082)^{\mathrm{b}}\end{array}$ & & \\
\hline 9 & $\begin{array}{l}1938,1856^{\mathrm{a}} \\
1923,1857^{\mathrm{b}} \\
1916,1846^{\mathrm{c}}\end{array}$ & $\begin{array}{l}432(1002), 504 \\
(839)^{\mathrm{a}} \\
435(1114), 503 \\
(1142)^{\mathrm{b}}\end{array}$ & $64^{\mathrm{a}}$ & $1.81 \pm 0.025^{\mathrm{a}}$ \\
\hline 12 & $\begin{array}{l}2005,1939^{a} \\
2003,1934^{b} \\
2002,1932^{c}\end{array}$ & $\begin{array}{l}503(1024), 629 \\
(391)^{\mathrm{a}} \\
502(1521), 662 \\
(476)^{\mathrm{b}}\end{array}$ & & \\
\hline 17 & $\begin{array}{l}1971,1910^{\mathrm{a}} \\
1968,1907^{\mathrm{b}}\end{array}$ & $\begin{array}{l}334(2613)^{\mathrm{a}} \\
331(645)^{\mathrm{b}}\end{array}$ & $533^{\mathrm{a}}$ & $0.22 \pm 0.002^{\mathrm{a}}$ \\
\hline 19 & $\begin{array}{l}2023,1938^{\mathrm{a}} \\
2027,1944^{\mathrm{e}} \\
2021,1933^{\mathrm{f}}\end{array}$ & $\begin{array}{l}332(1263)^{\mathrm{a}} \\
329(1487)^{\mathrm{e}}\end{array}$ & & \\
\hline 20 & $\begin{array}{l}1927,1862^{\mathrm{a}} \\
1938,1877^{\mathrm{e}} \\
1927,1856^{\mathrm{f}}\end{array}$ & $\begin{array}{l}371(898), 495 \\
(387)^{\mathrm{a}} \\
362(548), 500 \\
(252)^{\mathrm{e}}\end{array}$ & $205^{\mathrm{a}}$ & $0.56 \pm 0.003^{\mathrm{a}}$ \\
\hline 21 & $\begin{array}{l}2005,1936^{\mathrm{a}} \\
2002,1938^{\mathrm{e}}\end{array}$ & $\begin{array}{l}509(946), 639 \\
(251)^{\mathrm{a}}\end{array}$ & & \\
\hline
\end{tabular}




\begin{tabular}{|l|l|l|l|l|}
\hline & $2006,1934^{\mathrm{f}}$ & $\begin{array}{l}507(1026), 651 \\
(383)^{\mathrm{e}}\end{array}$ & & \\
\hline
\end{tabular}

$\mathrm{a}$ - in benzene, $\mathrm{b}$ - in THF, $\mathrm{c}-$ in $\mathrm{CH}_{3} \mathrm{CN}, \mathrm{d}-$ in gas phase, $\mathrm{e}-$ in cyclohexane, $\mathrm{f}-$ in capillary layer. 


\section{IR spectra}

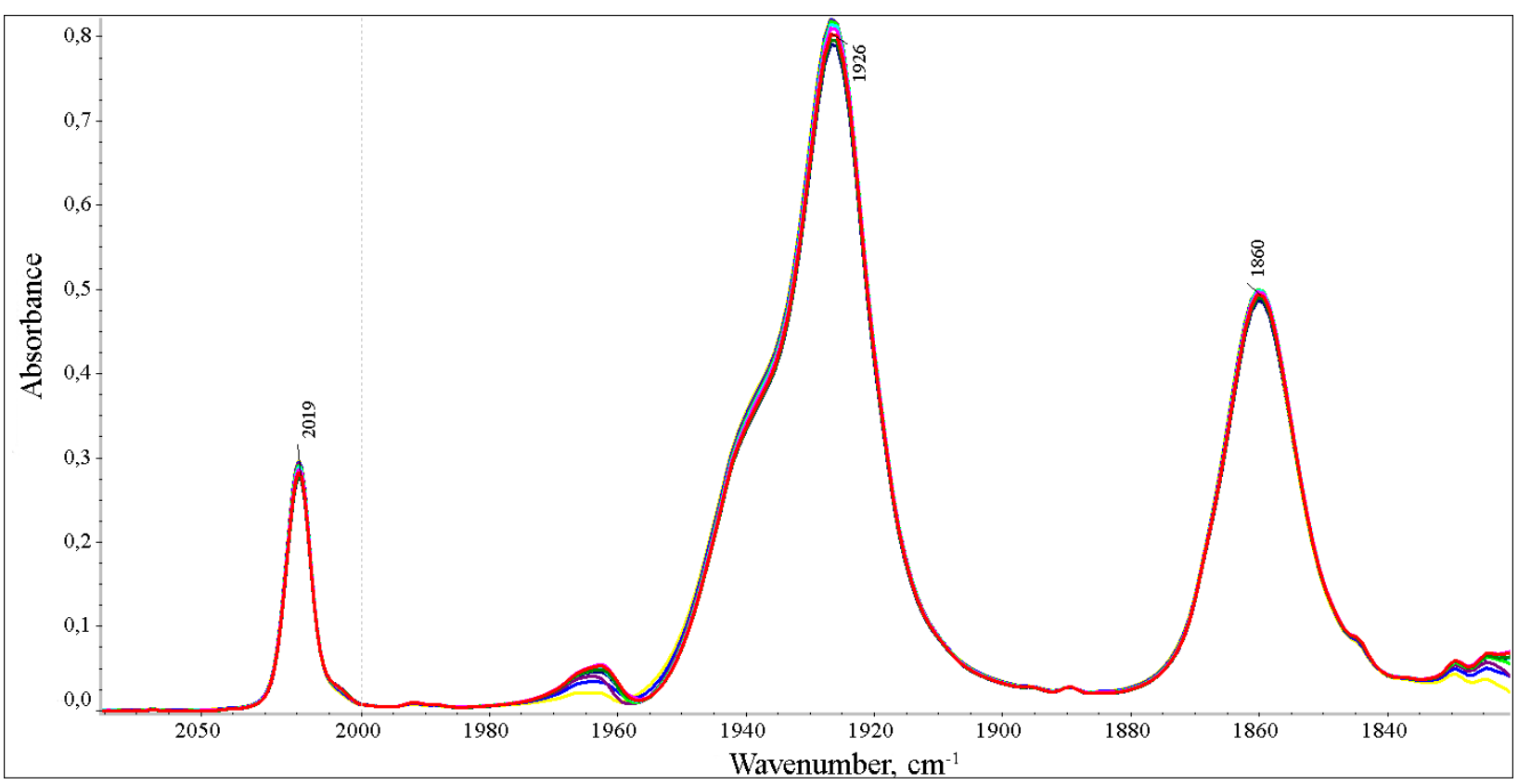

Figure S1. IR monitoring in the $v(\mathrm{CO})$ region of the dark thermal reaction of $\mathbf{7}$ to $\mathbf{4}$ in benzene for $140 \mathrm{~min}$.

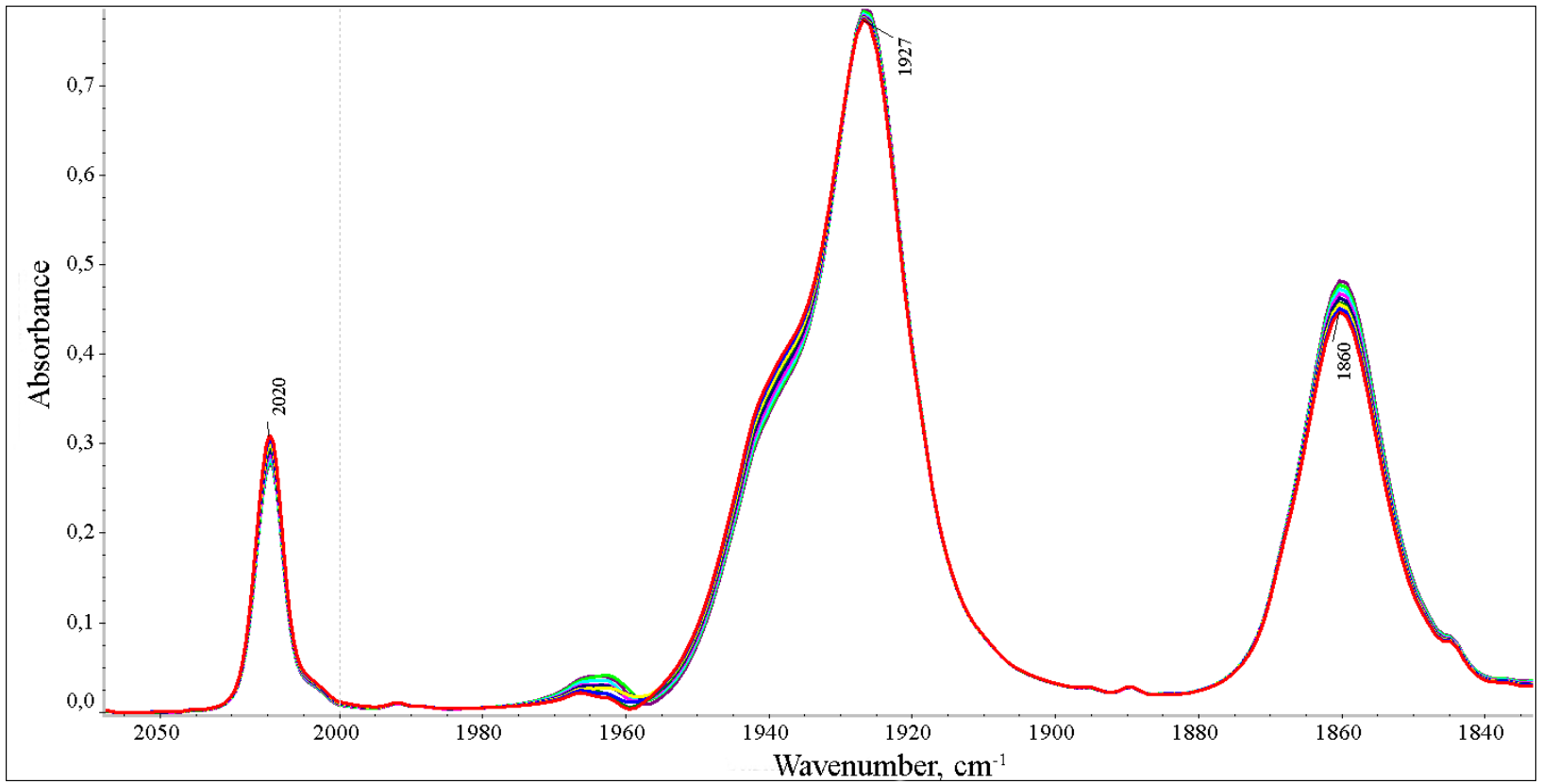

Figure S2. IR monitoring in the $v(\mathrm{CO})$ region of the dark thermal reaction of $\mathbf{7}$ to 4 in acetonitrile for $120 \mathrm{~min}$. 


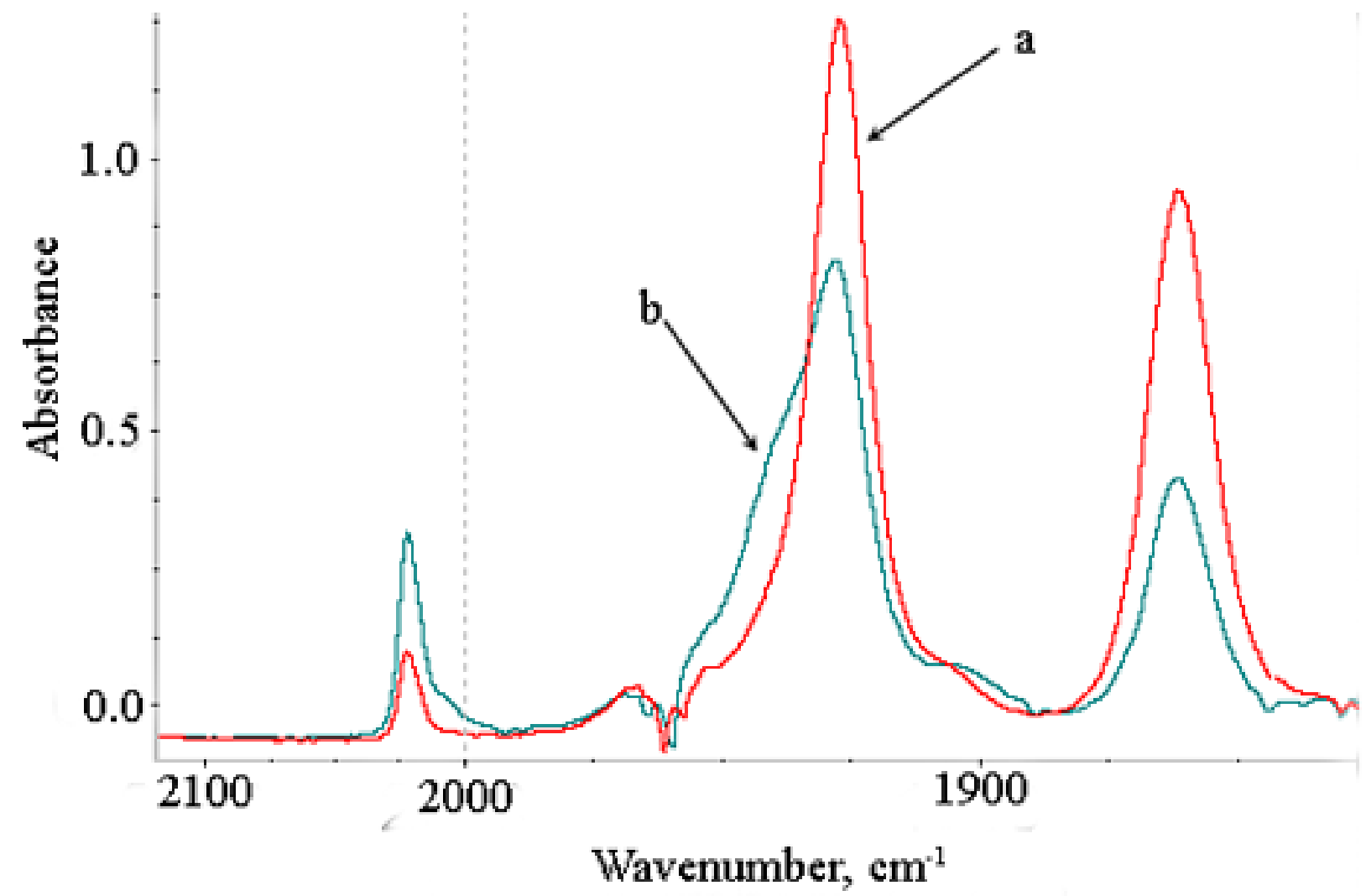

Figure S3. IR spectra in the $v(\mathrm{CO})$ region in benzene: a) after irradiation of 5 ; b) the dark thermal reaction of $\mathbf{8}$ to $\mathbf{5}$ after $430 \mathrm{~min}$.

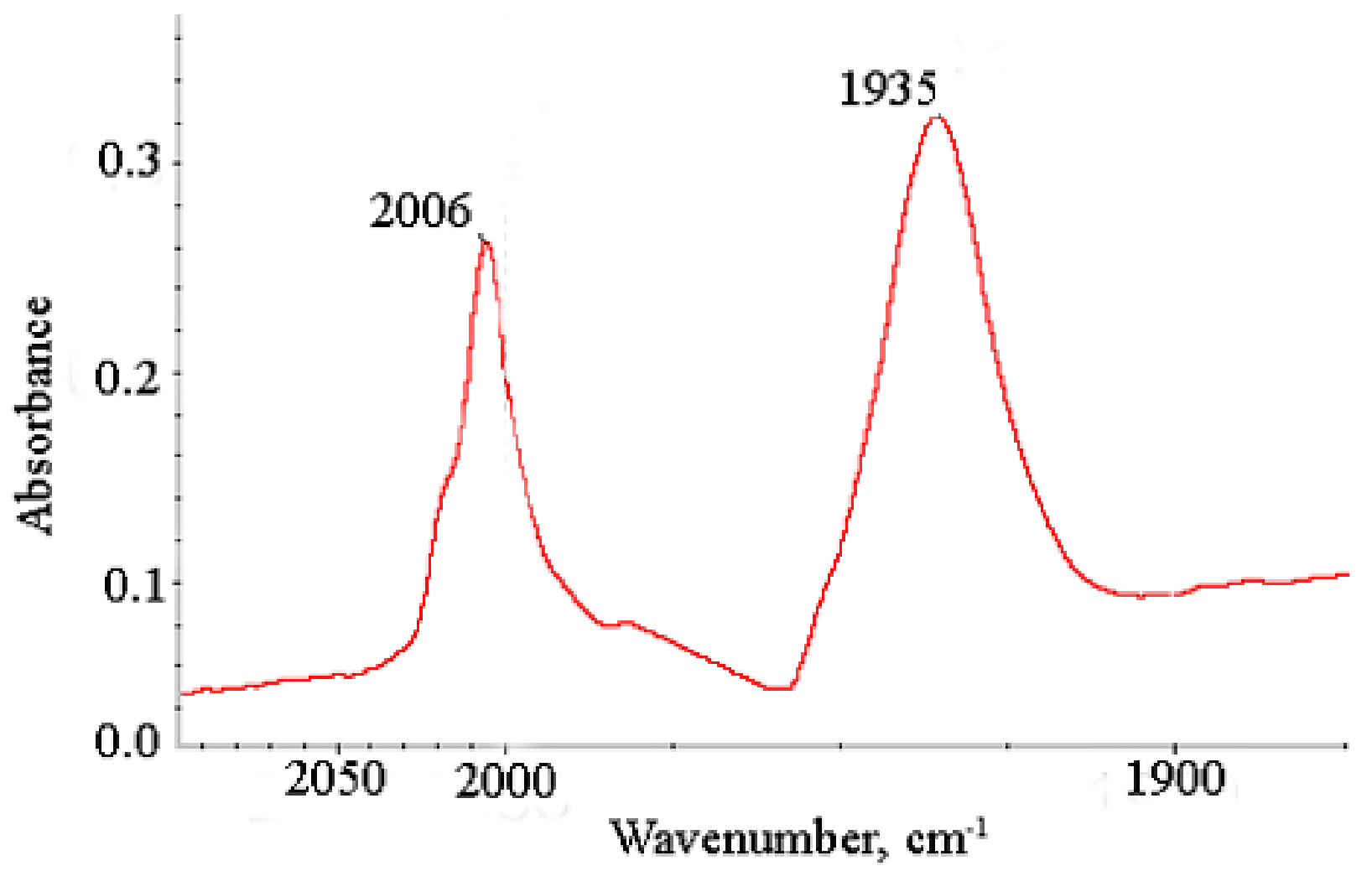

Figure S4. IR spectrum in the $v(\mathrm{CO})$ region of compound $\mathbf{1 0}$ in benzene. 


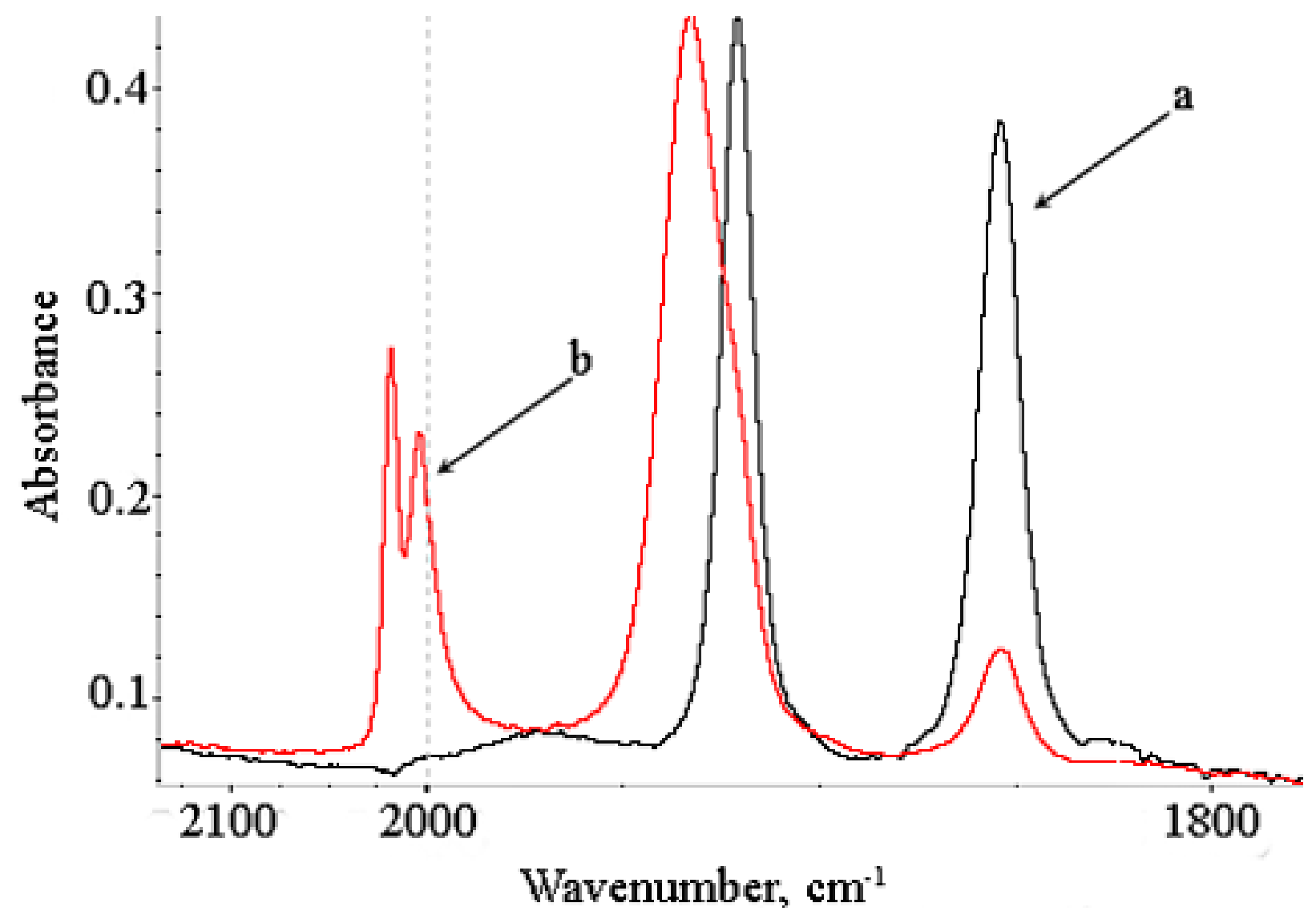

Figure S5. IR spectra in the $v(\mathrm{CO})$ region in benzene: a) after irradiation of $\mathbf{6}$; b) the dark thermal reaction of $\mathbf{9}$ to $\mathbf{6}$ and $\mathbf{1 2}$ in the presence of air and CO for $620 \mathrm{~min}$.

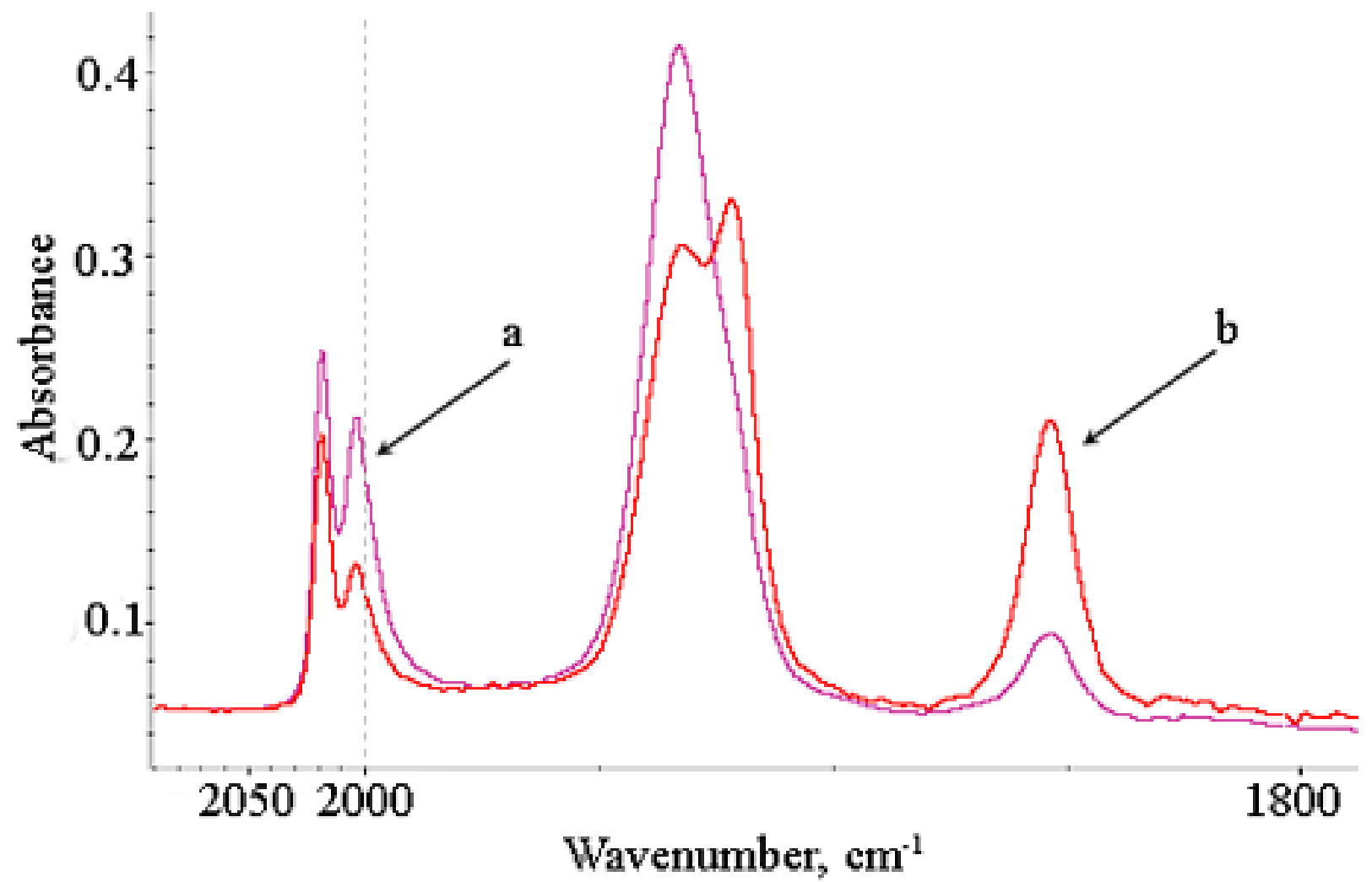

Figure S6. IR spectra in the $v(\mathrm{CO})$ region in benzene: a) after the dark thermal reaction of 9 to 6 and $\mathbf{1 2}$ in the presence of air and CO; b) the photolysis of $\mathbf{6}$ and $\mathbf{1 2}$ for $6 \mathrm{~min}$. 


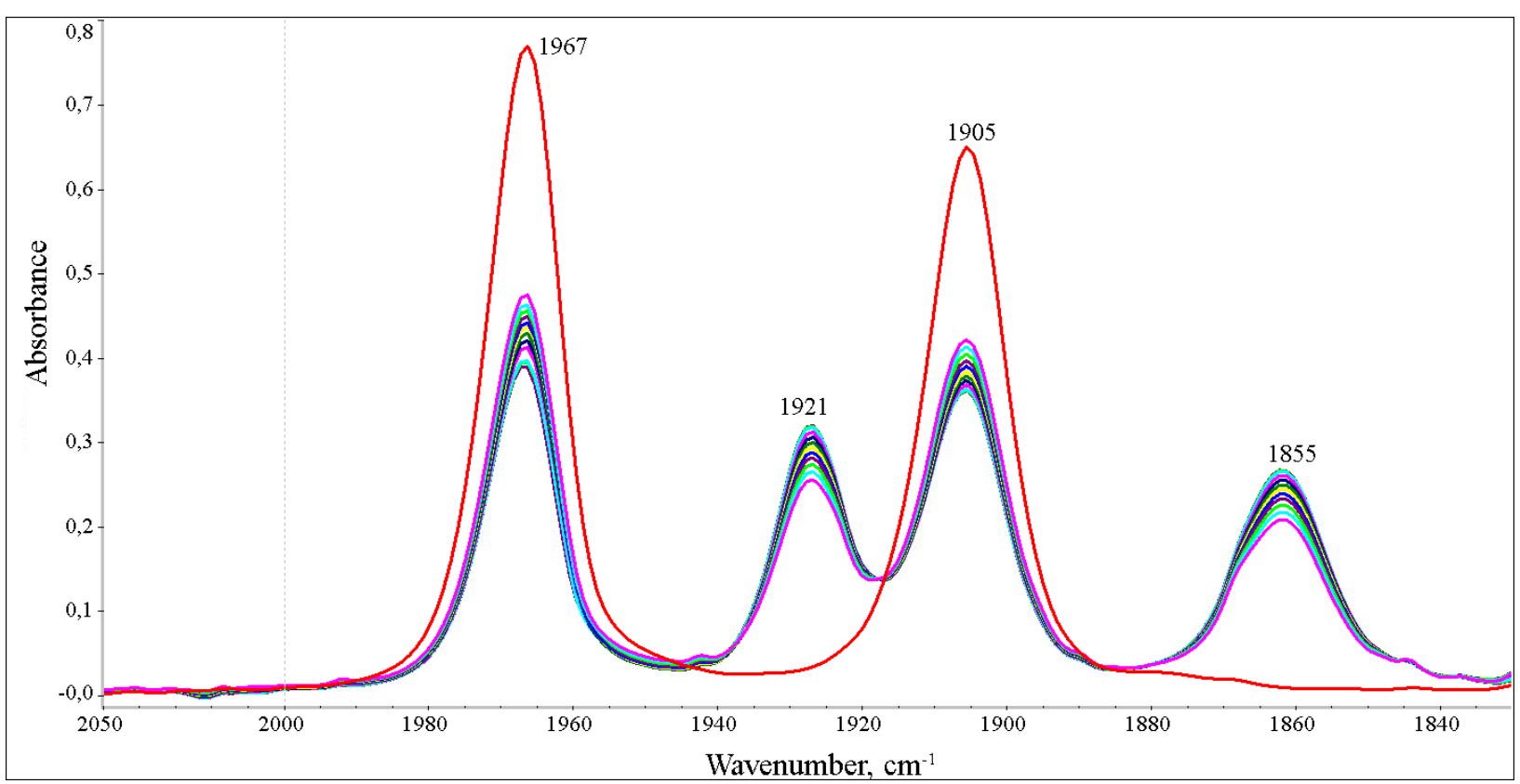

Figure S7. IR monitoring in the $v(\mathrm{CO})$ region of the dark isomerization of $\mathbf{8}$ to $\mathbf{1 6}$ in benzene for $180 \mathrm{~min}$.

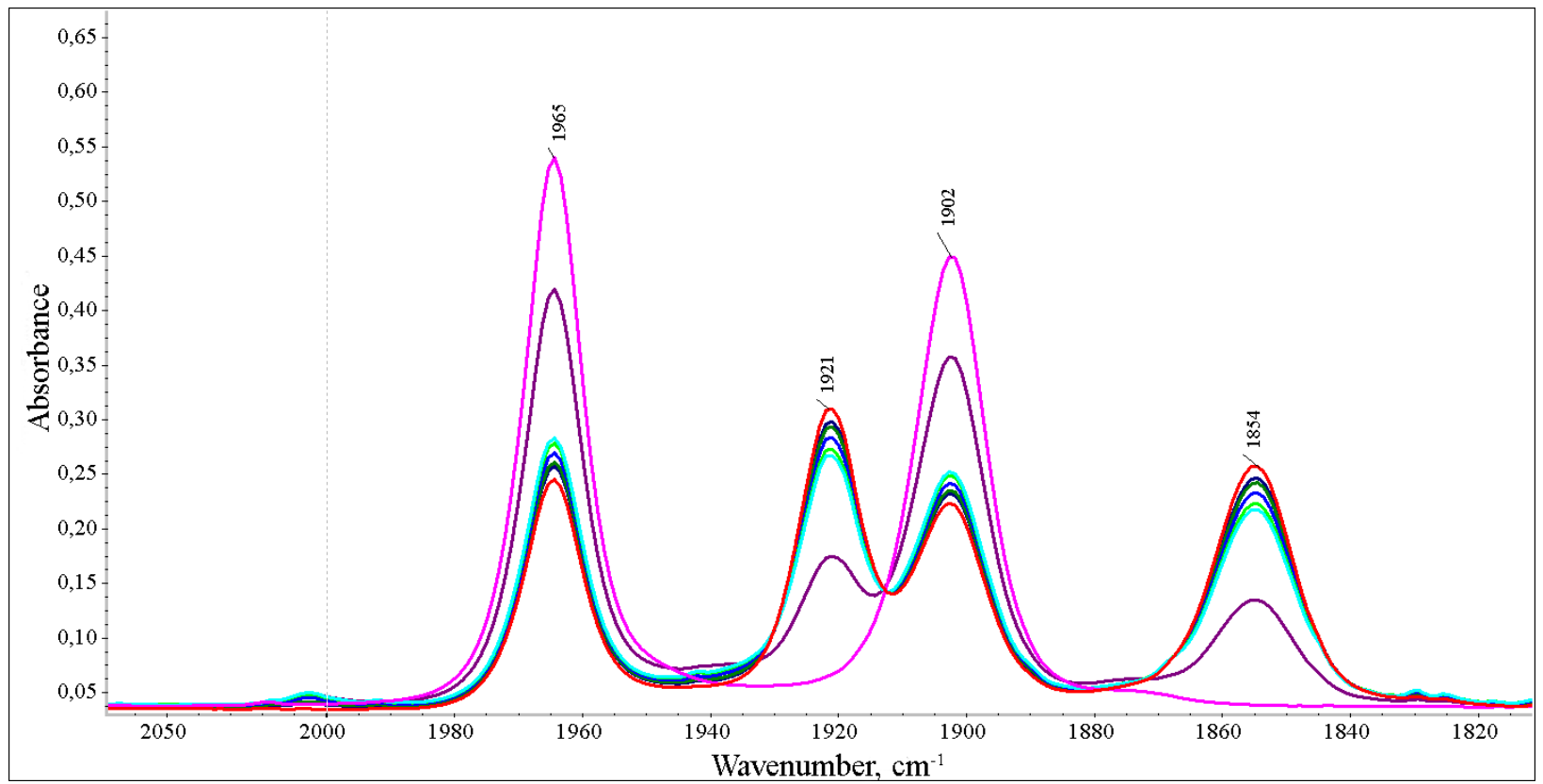

Figure S8. IR monitoring in the $v(\mathrm{CO})$ region of the dark isomerization of $\mathbf{8}$ to $\mathbf{1 6}$ in THF for $230 \mathrm{~min}$. 


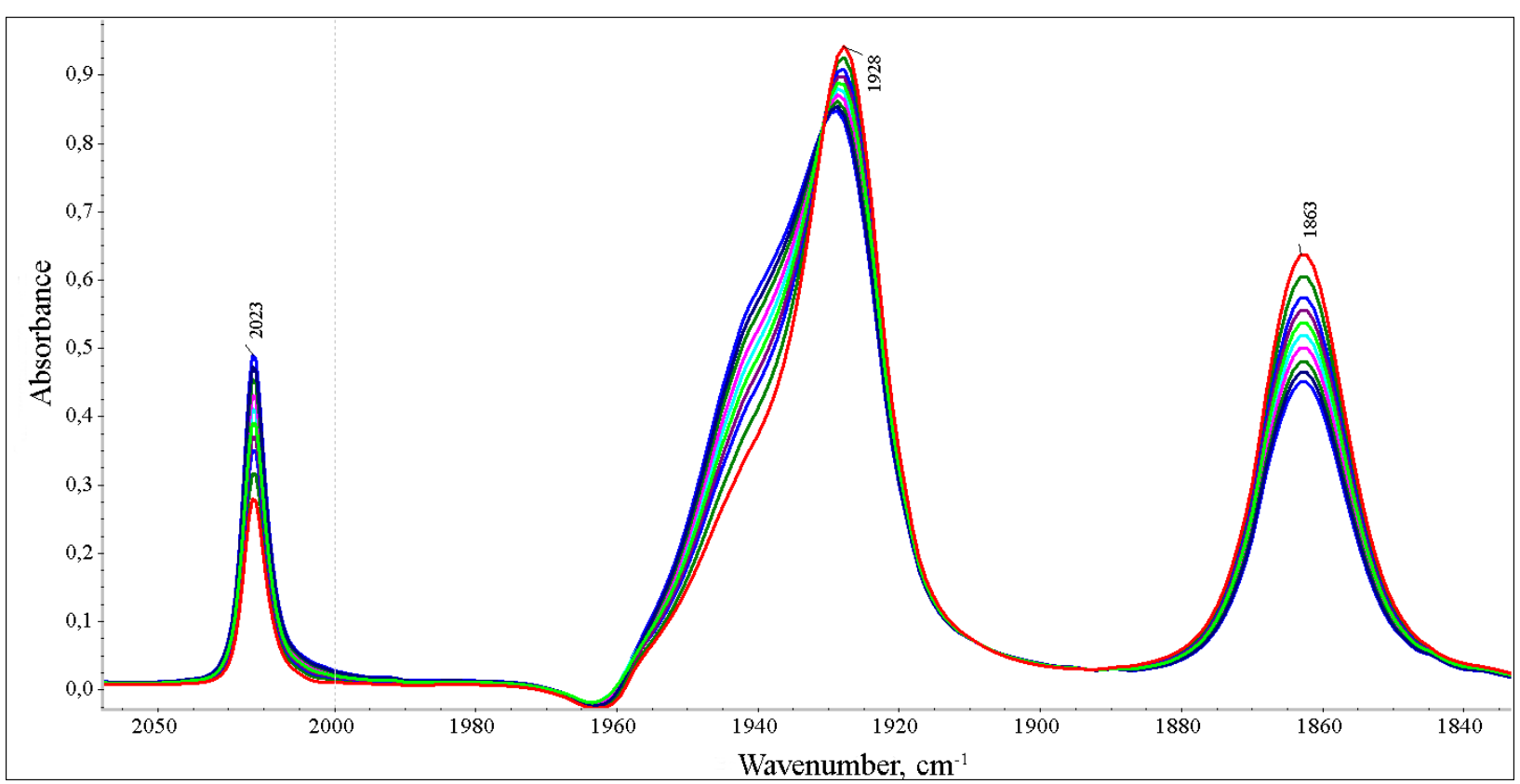

Figure S9. IR monitoring in the $v(\mathrm{CO})$ region of the dark isomerization of $\mathbf{2 0}$ to $\mathbf{1 9}$ in benzene for $200 \mathrm{~min}$.

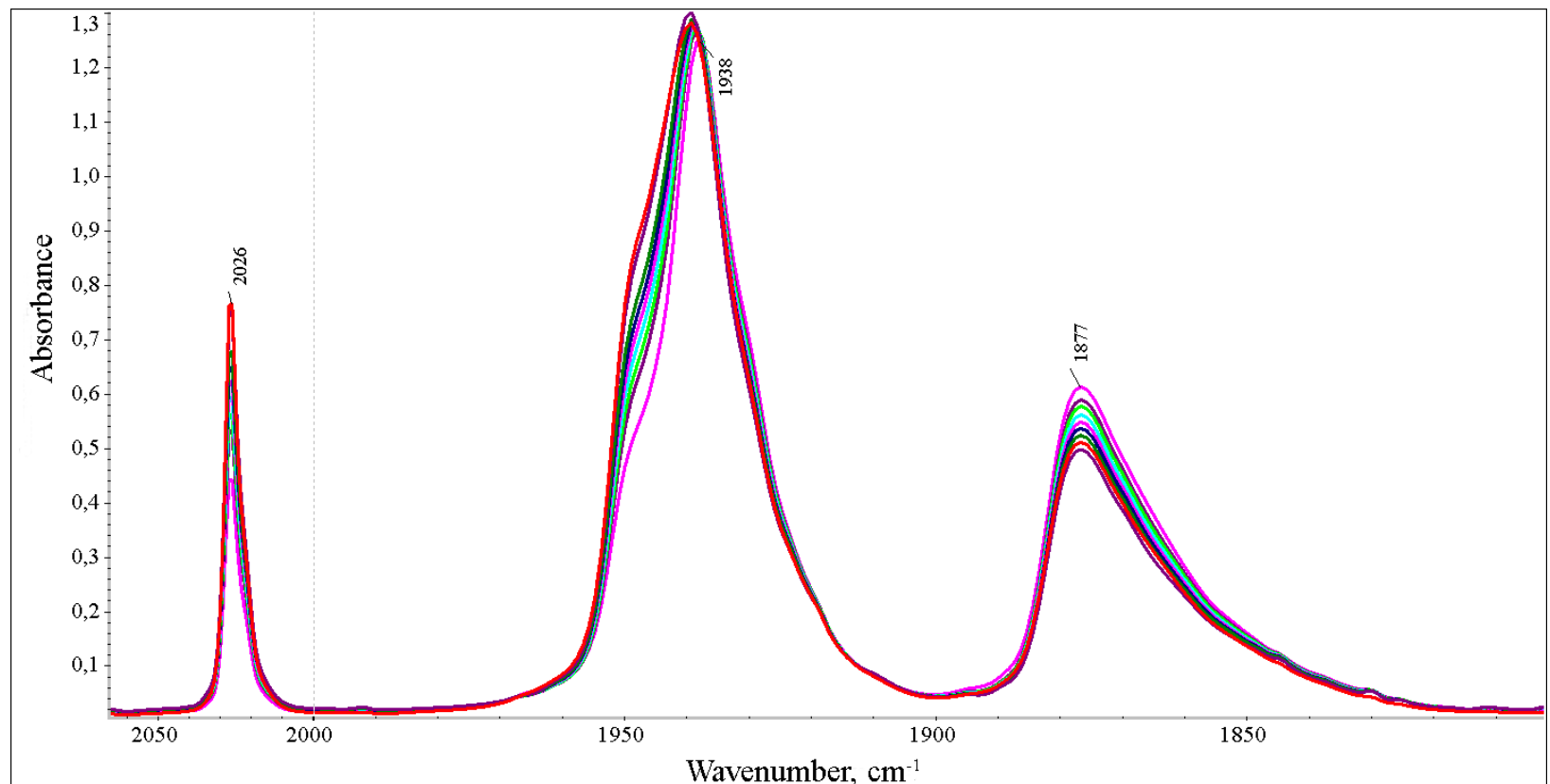

Figure S10. IR monitoring in the $v(\mathrm{CO})$ region of the dark isomerization of 20 to 19 in cyclohexane for $180 \mathrm{~min}$. 


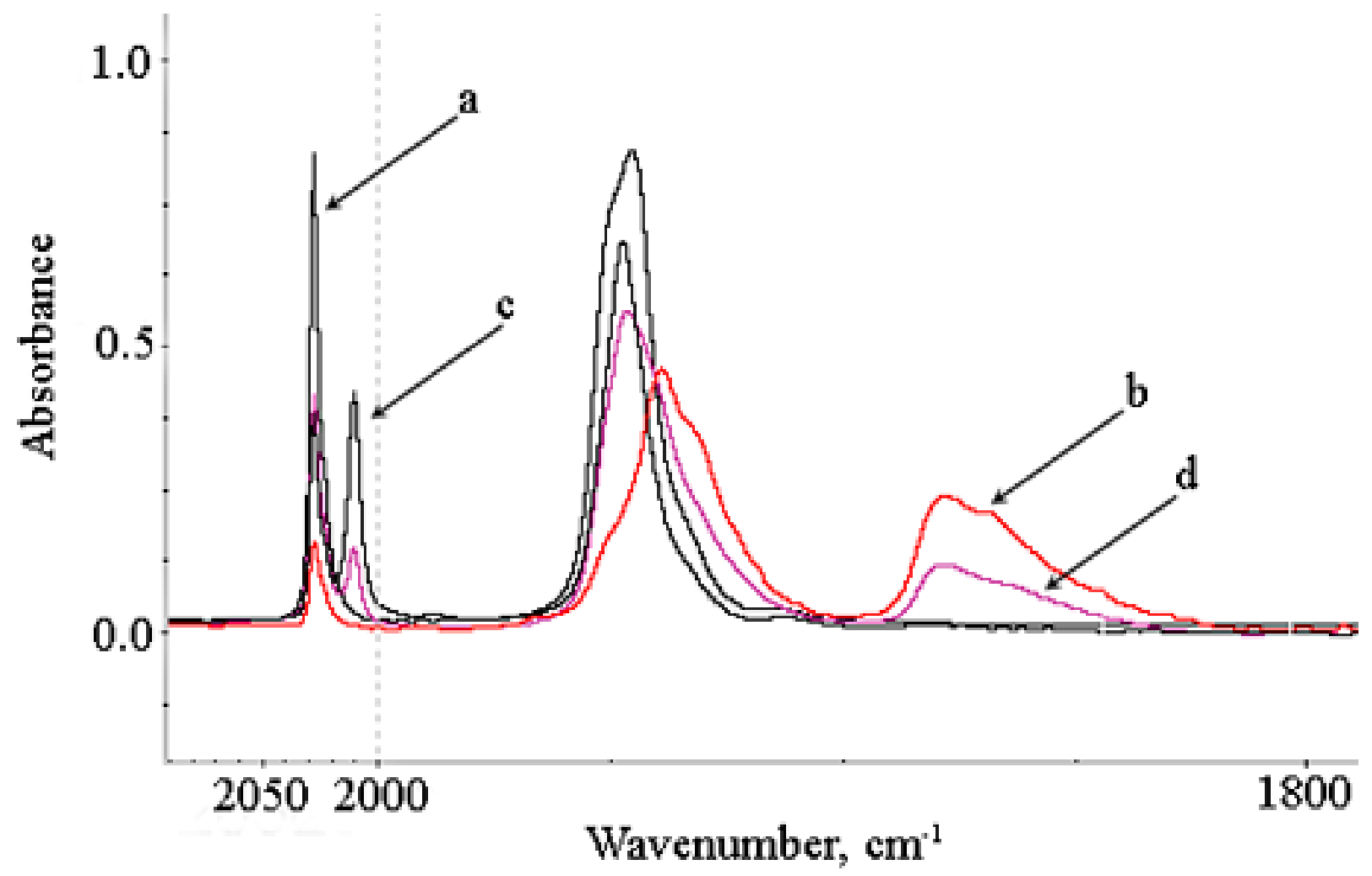

Figure S11. IR monitoring in the $v(\mathrm{CO})$ region in cyclohexane: a) the spectrum of 19 ; b) the photolysis of $\mathbf{1 9}$ for $6 \mathrm{~min}$; c) the dark thermal reaction of $\mathbf{2 0}$ to $\mathbf{1 9}$ and $\mathbf{2 1}$ in the absence of air and $\mathrm{CO}$; d) the photolysis of $\mathbf{1 9}$ and $\mathbf{2 1}$ for 2 min. 


\section{${ }^{1}$ H NMR spectra}

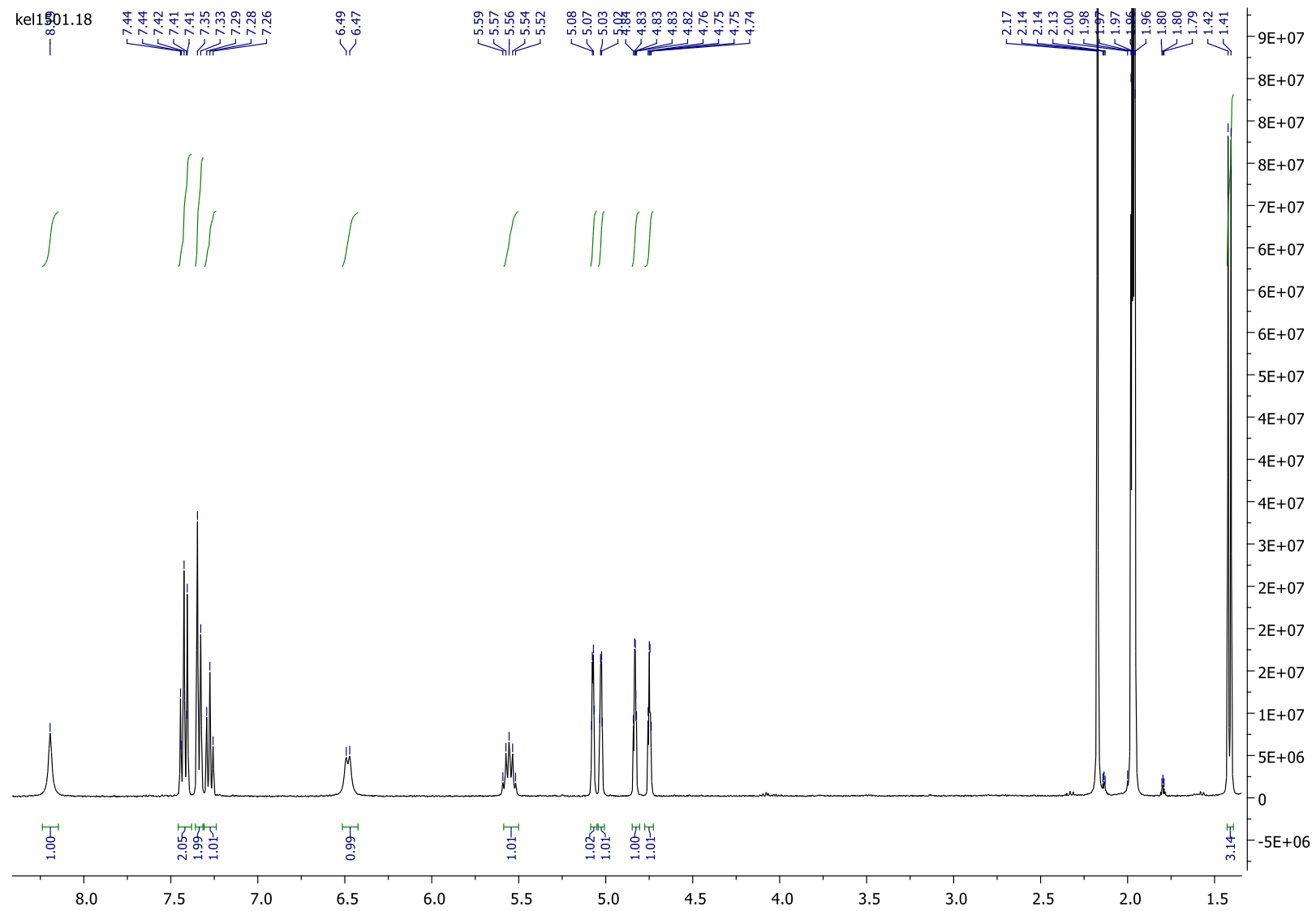

Figure S12. ${ }^{1}$ H NMR spectra of compound 4 in acetonitrile- $d_{3}$.

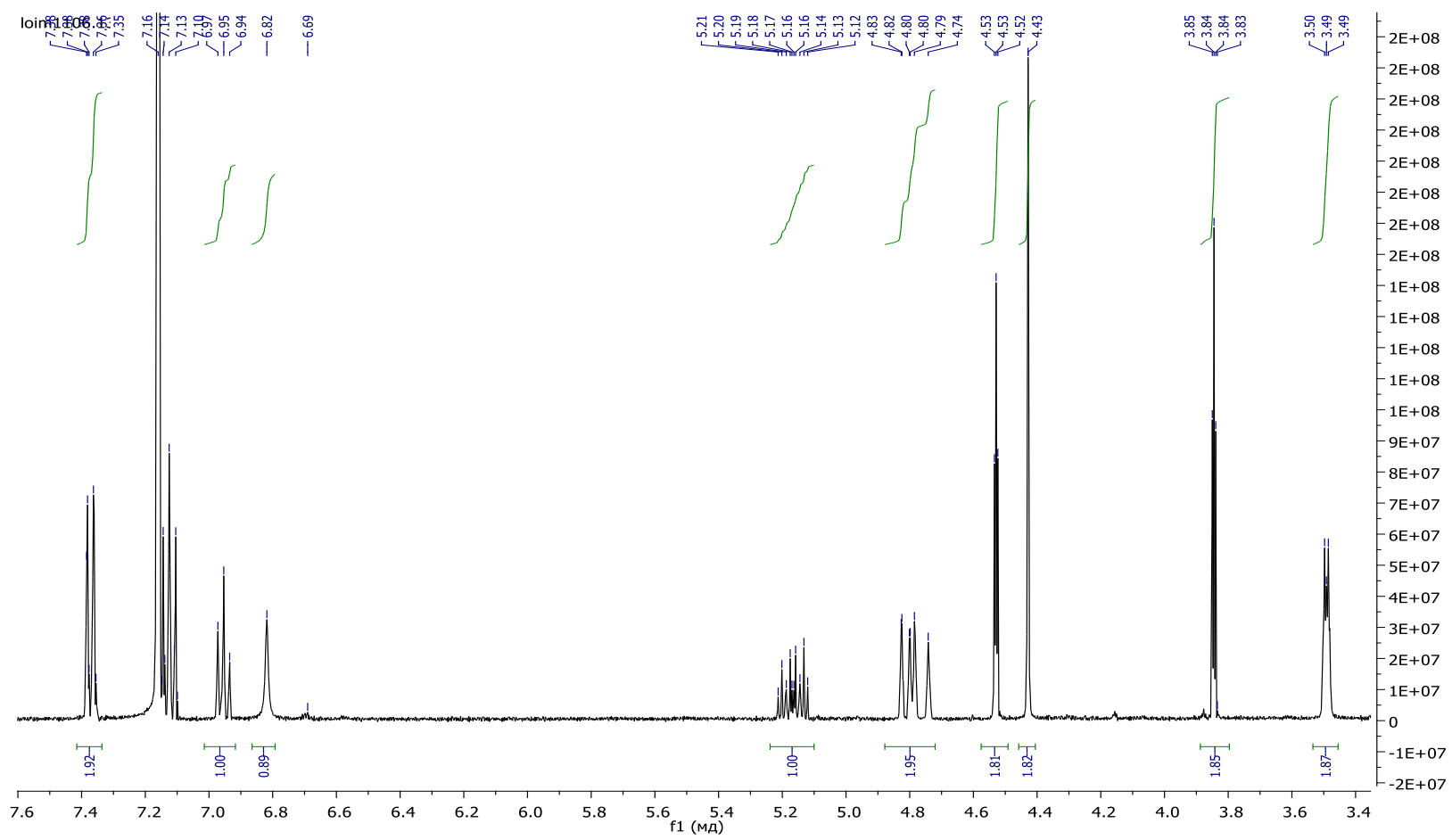

Figure S13. ${ }^{1} \mathrm{H}$ NMR spectra of compound 5 in deuterobenzene. 


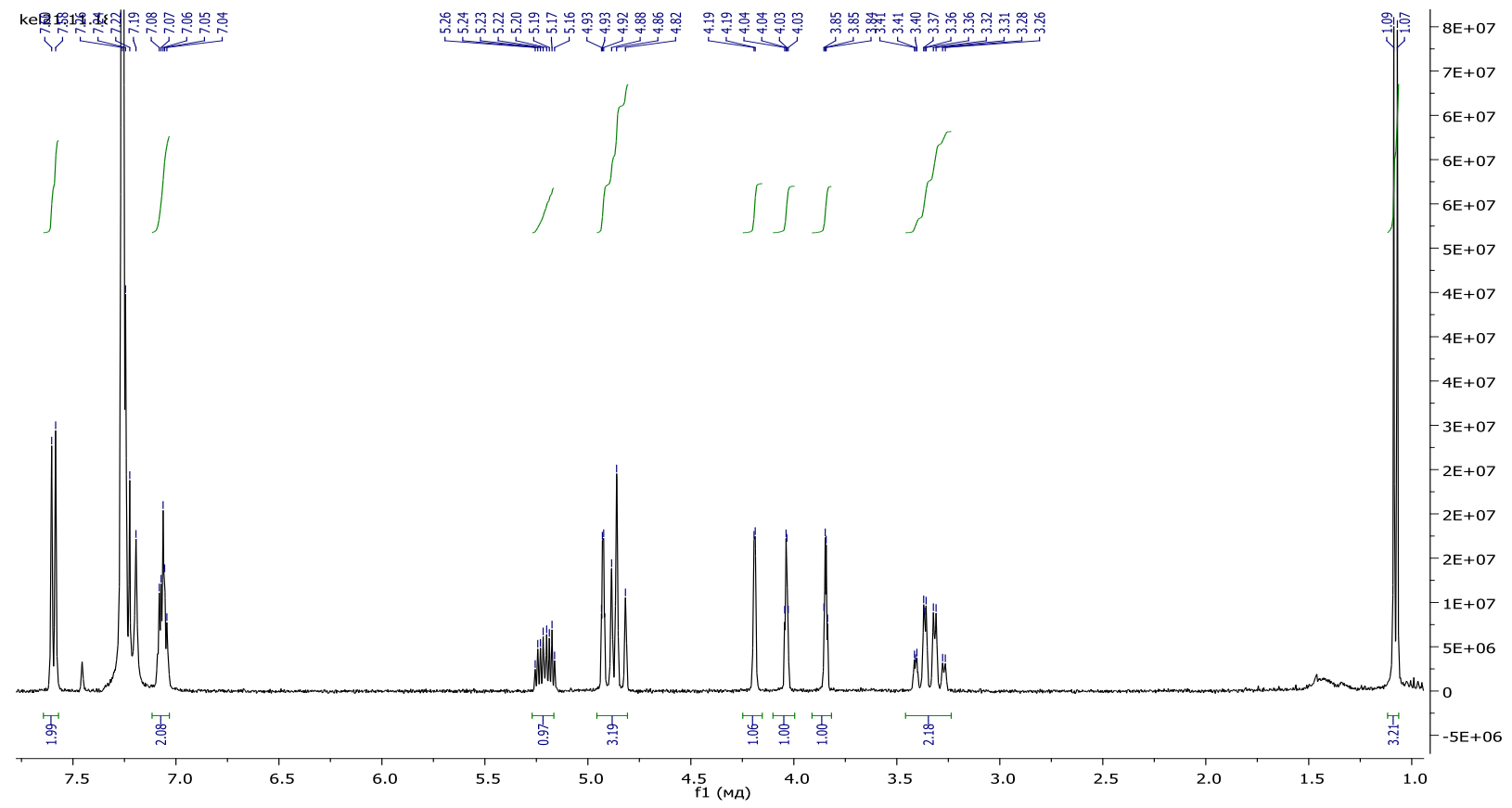

Figure S14. ${ }^{1} \mathrm{H}$ NMR spectra of compound 6 in deuterobenzene.

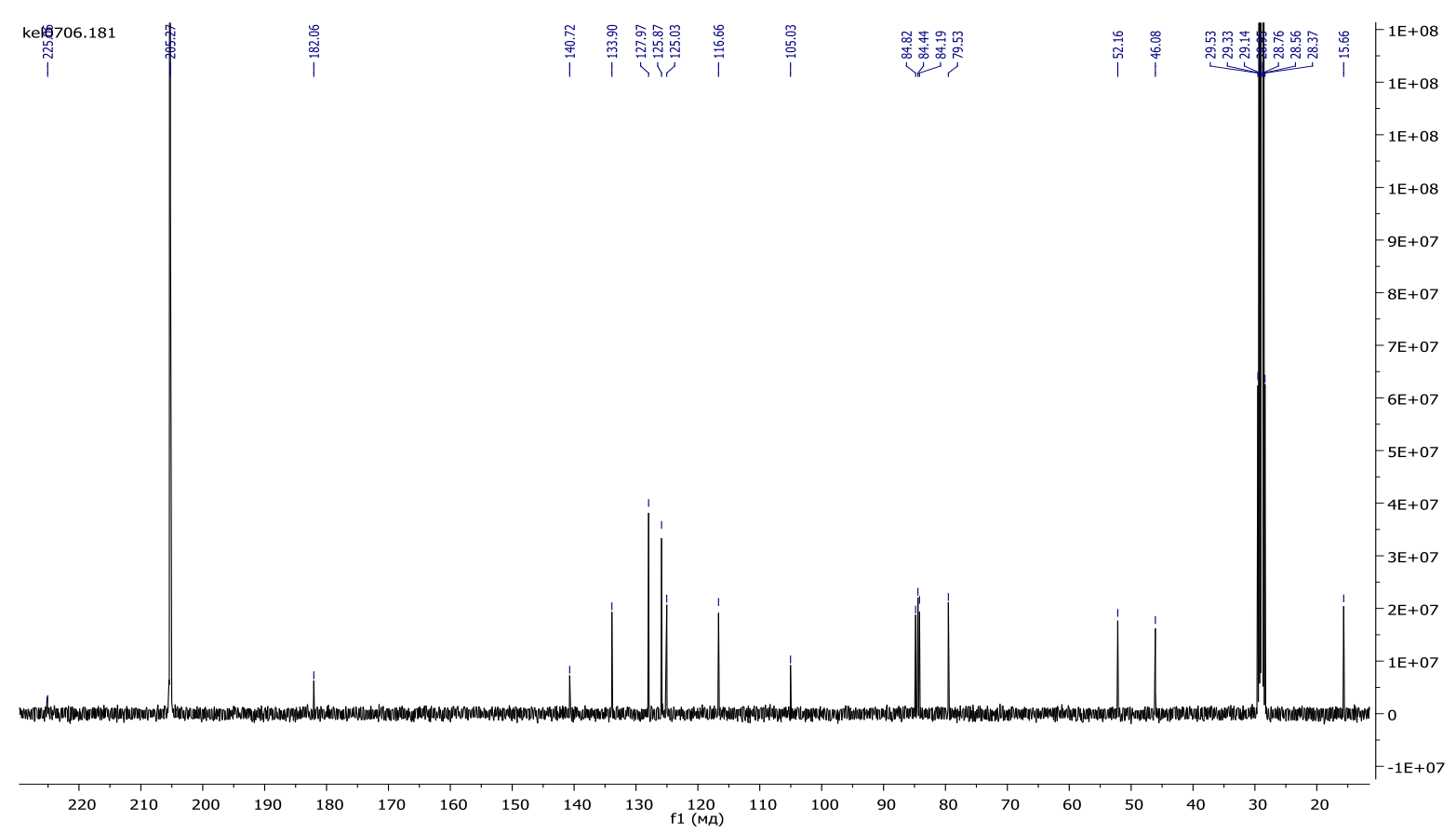

Figure S15. ${ }^{13} \mathrm{C}$ NMR spectra of compound 6 in acetone-d6. 


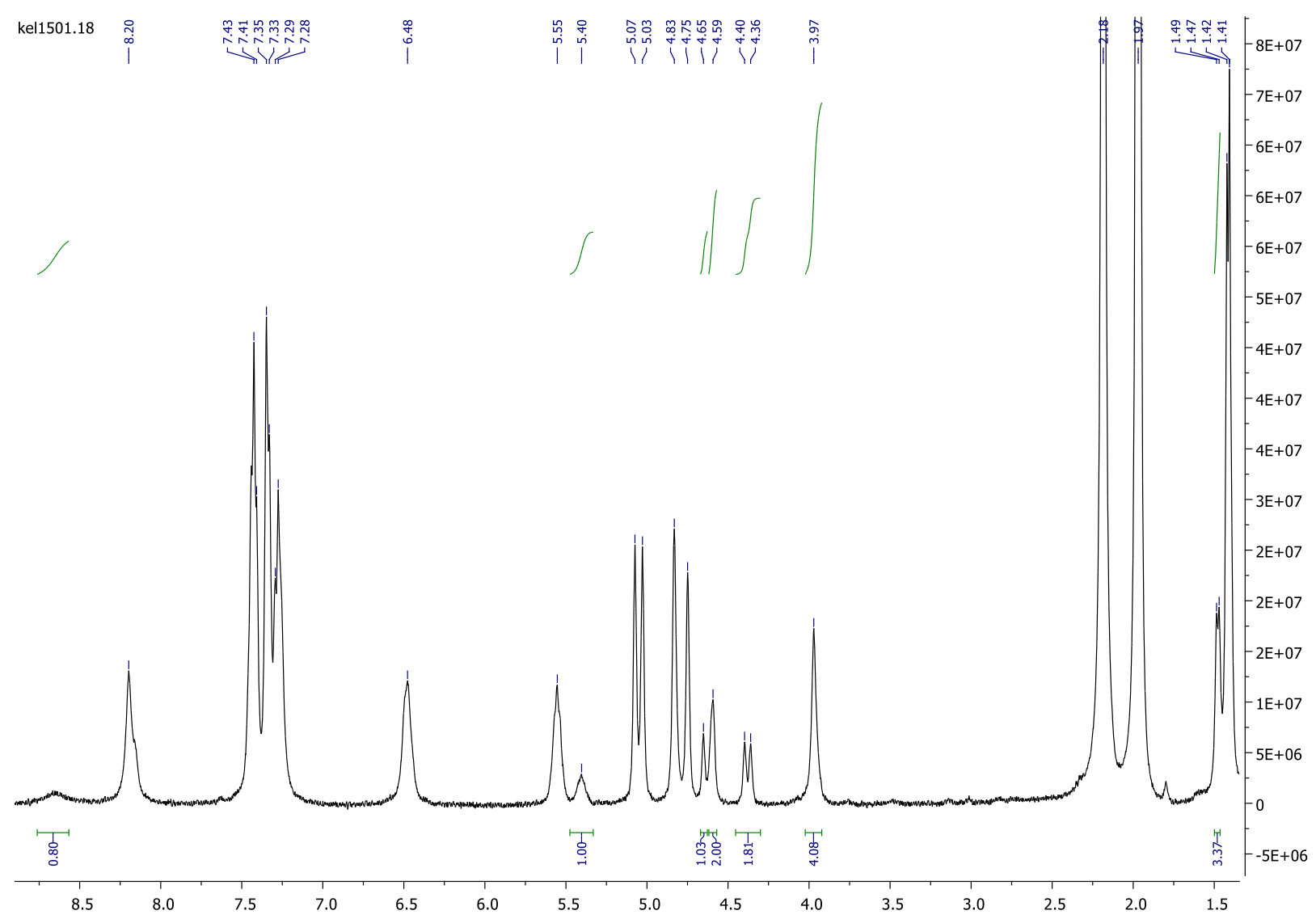

Figure S16. ${ }^{1} \mathrm{H}$ NMR spectra of irradiation of compound 4 in acetonitrile-d $\mathrm{d}_{3}$ for $4 \mathrm{~min}$.

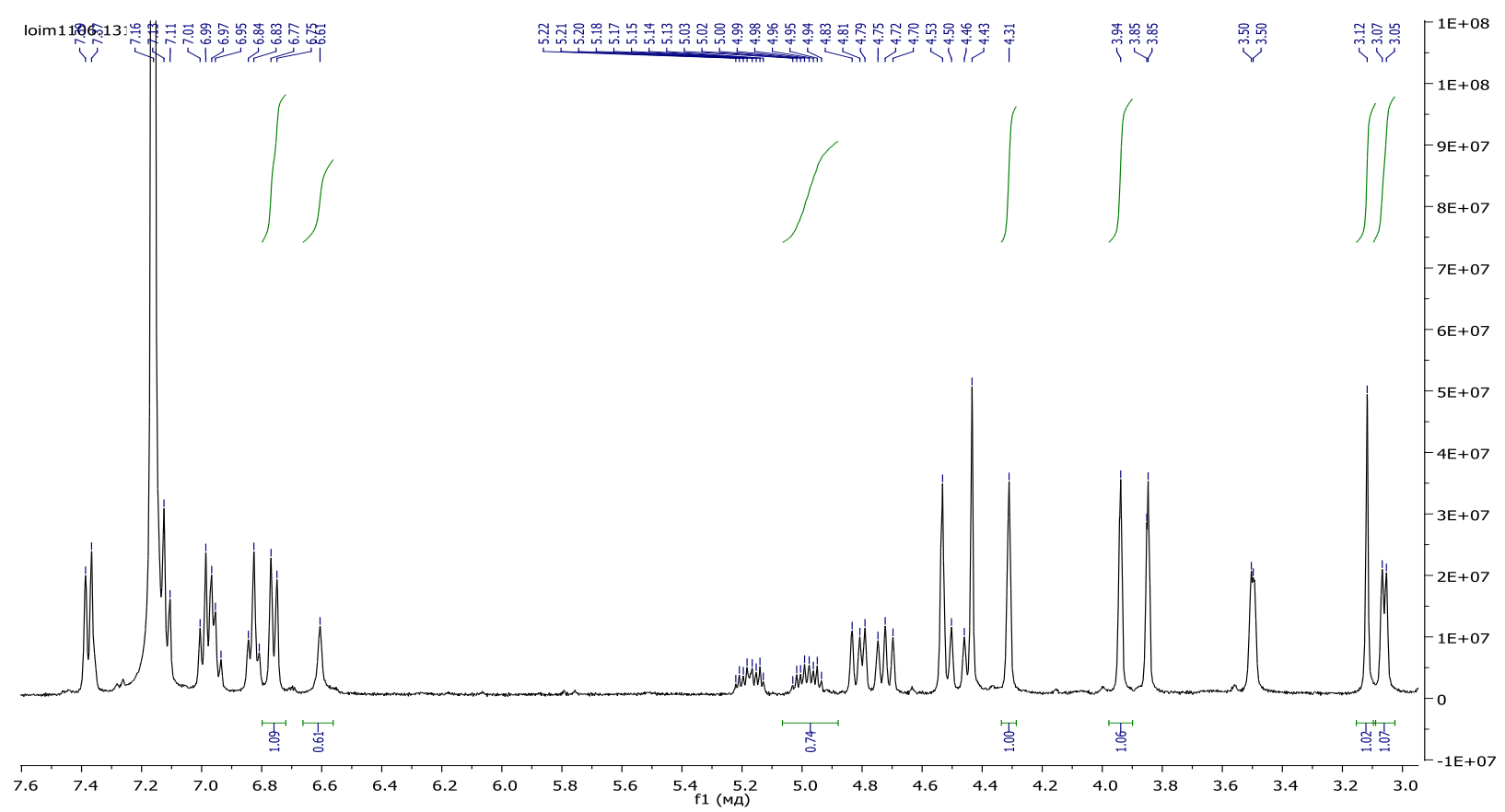

Figure S17. ${ }^{1} \mathrm{H}$ NMR spectra of irradiation of compound 5 in deuterobenzene for $4 \mathrm{~min}$. 


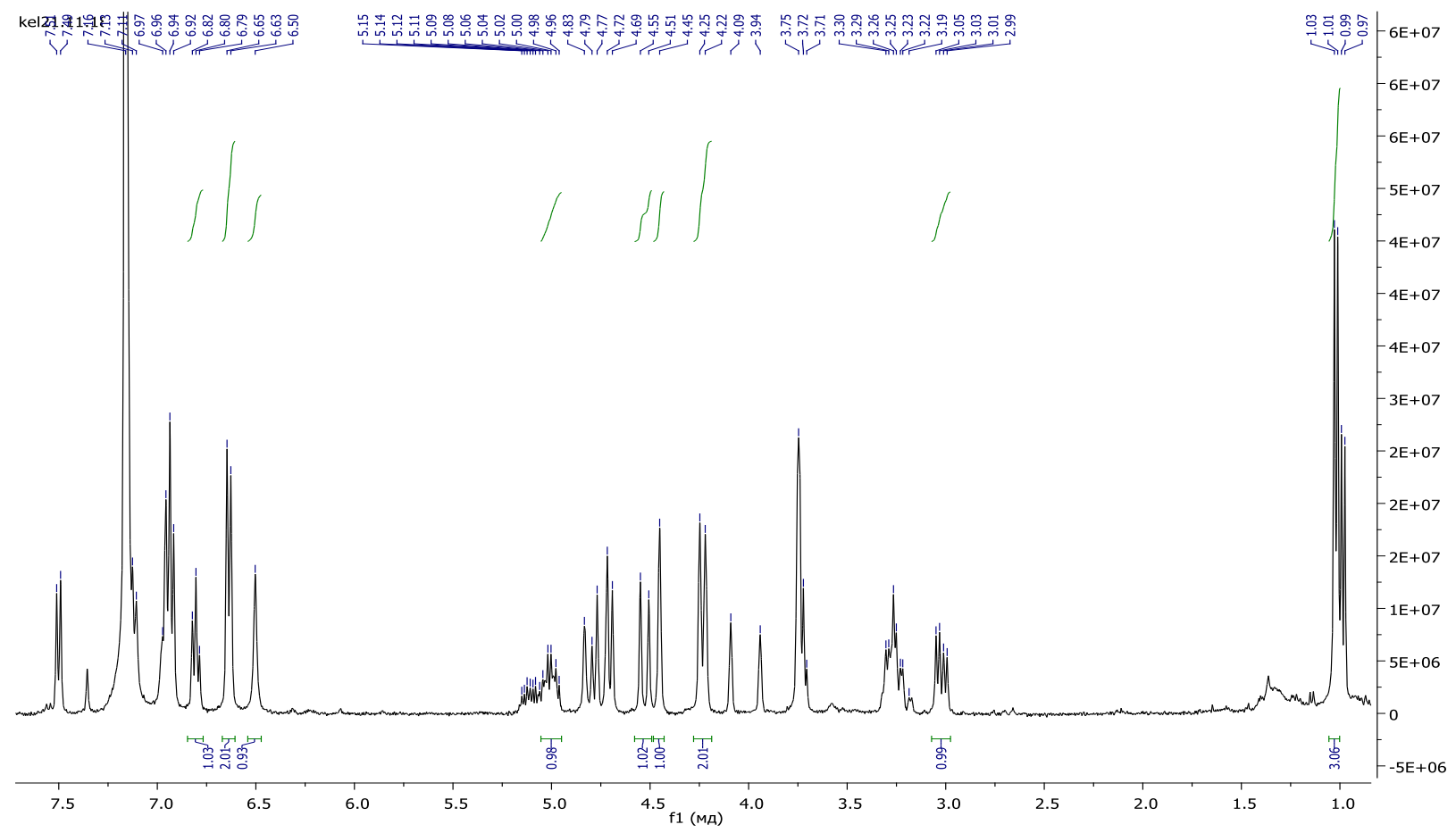

Figure S18. ${ }^{1} \mathrm{H}$ NMR spectra of irradiation of compound 6 in deuterobenzene for $4 \mathrm{~min}$.

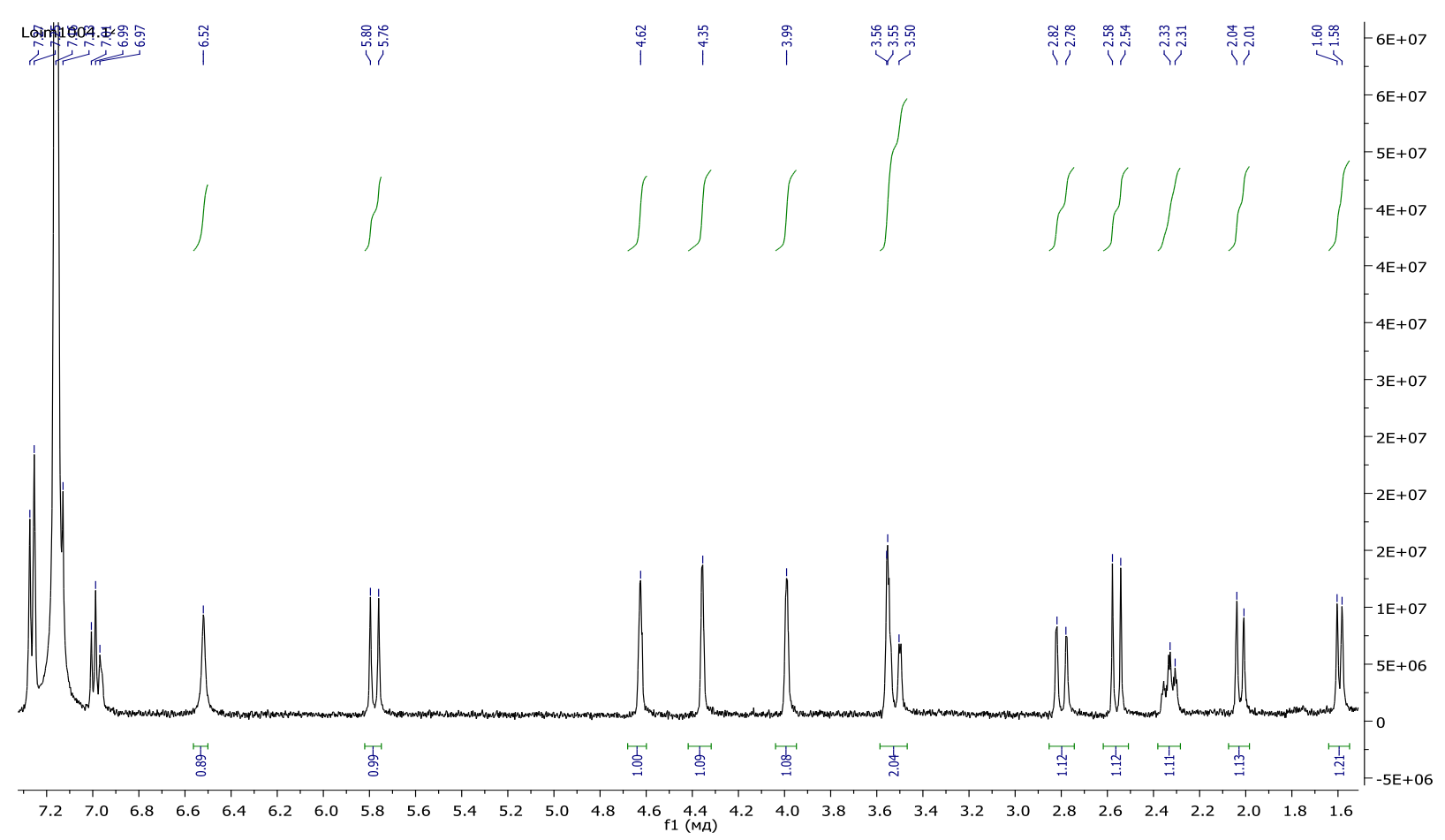

Figure S19. ${ }^{1} \mathrm{H}$ NMR spectra of compound 16 in deuterobenzene. 


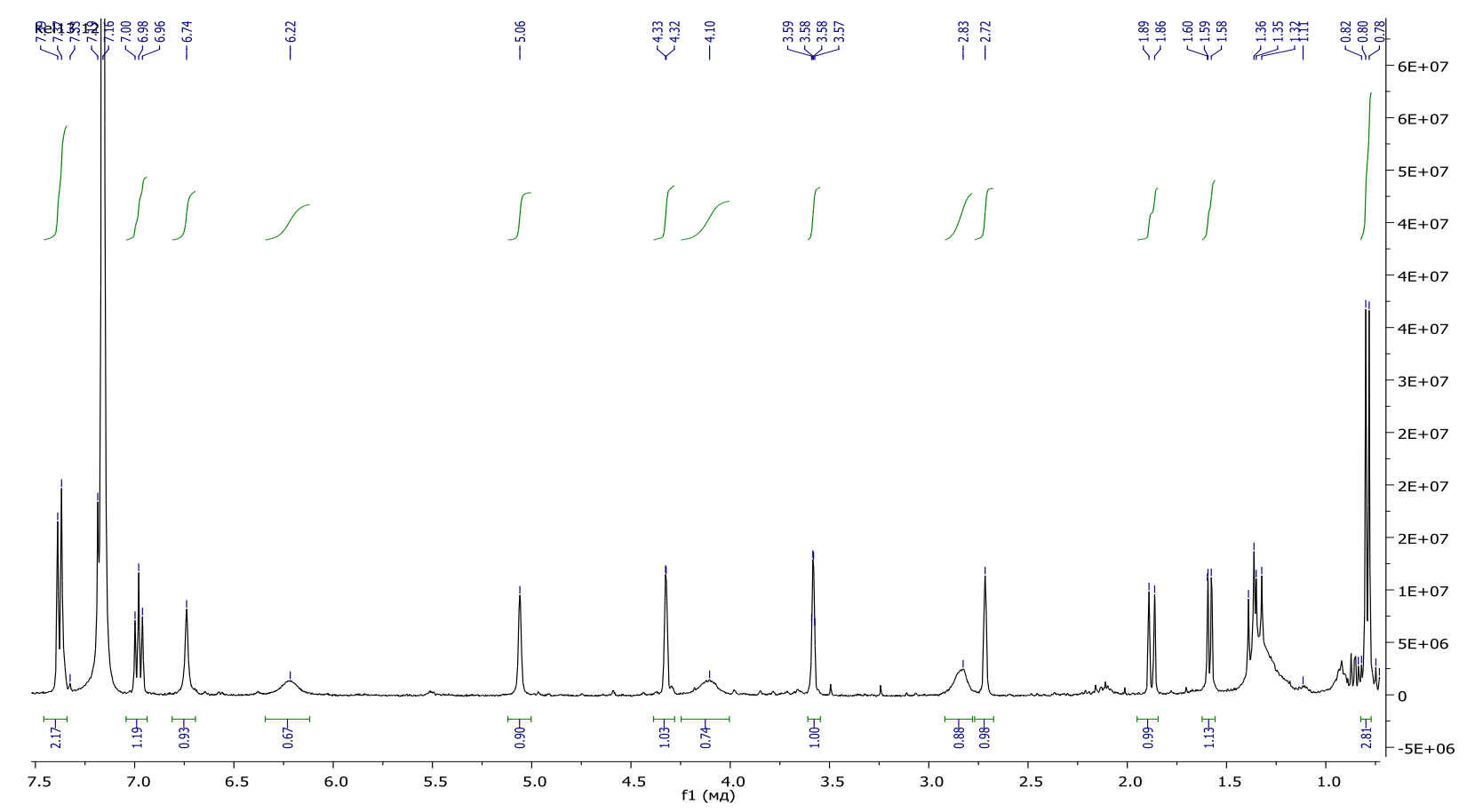

Figure S20. ${ }^{1} \mathrm{H}$ NMR spectra of compound 17 in deuterobenzene.

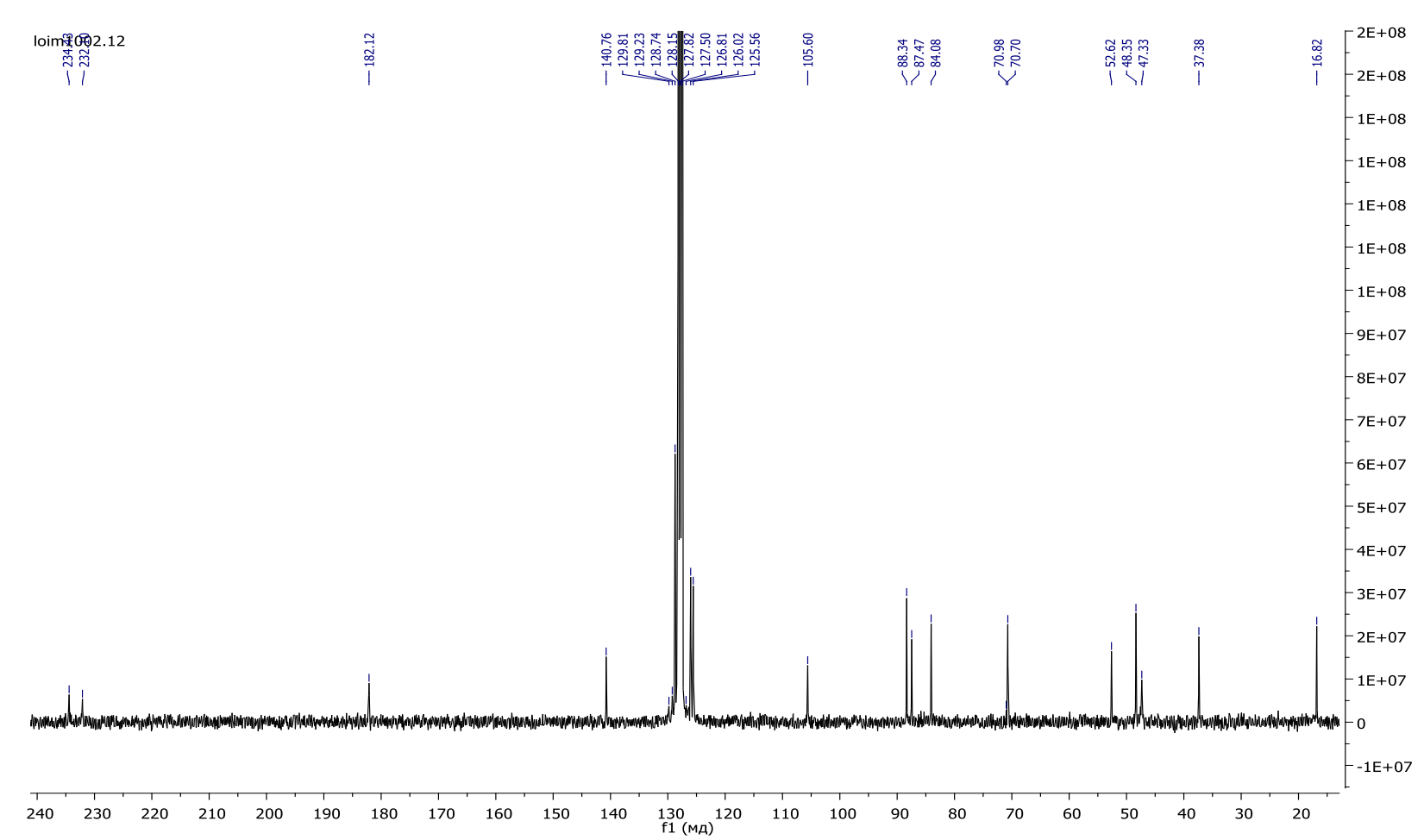

Figure S21. ${ }^{13} \mathrm{C}$ NMR spectra of compound $\mathbf{1 7}$ in deuterobenzene. 


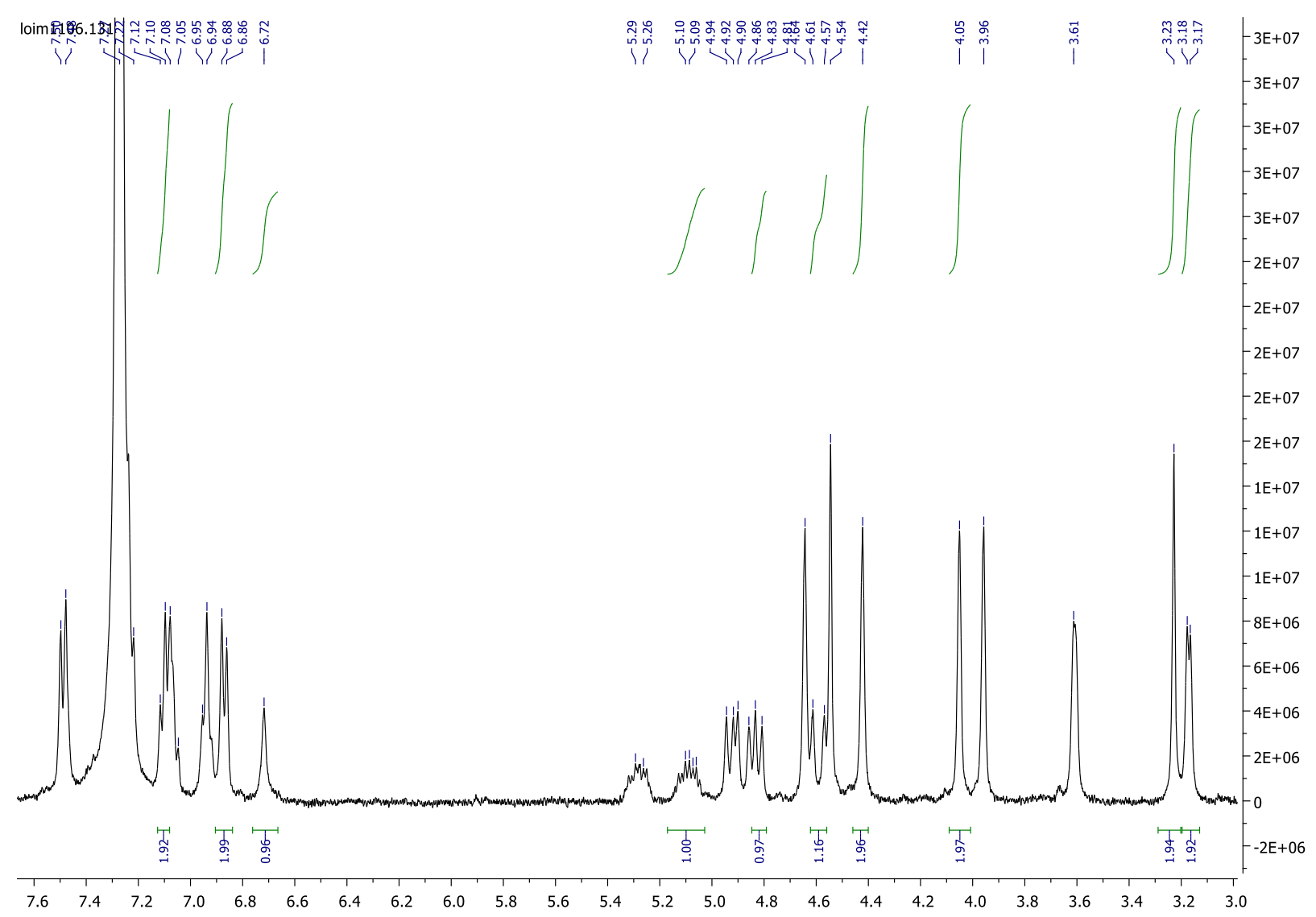

Figure S22. ${ }^{1} \mathrm{H}$ NMR spectra of irradiation of compound $\mathbf{1 6}$ in deuterobenzene for $4 \mathrm{~min}$.

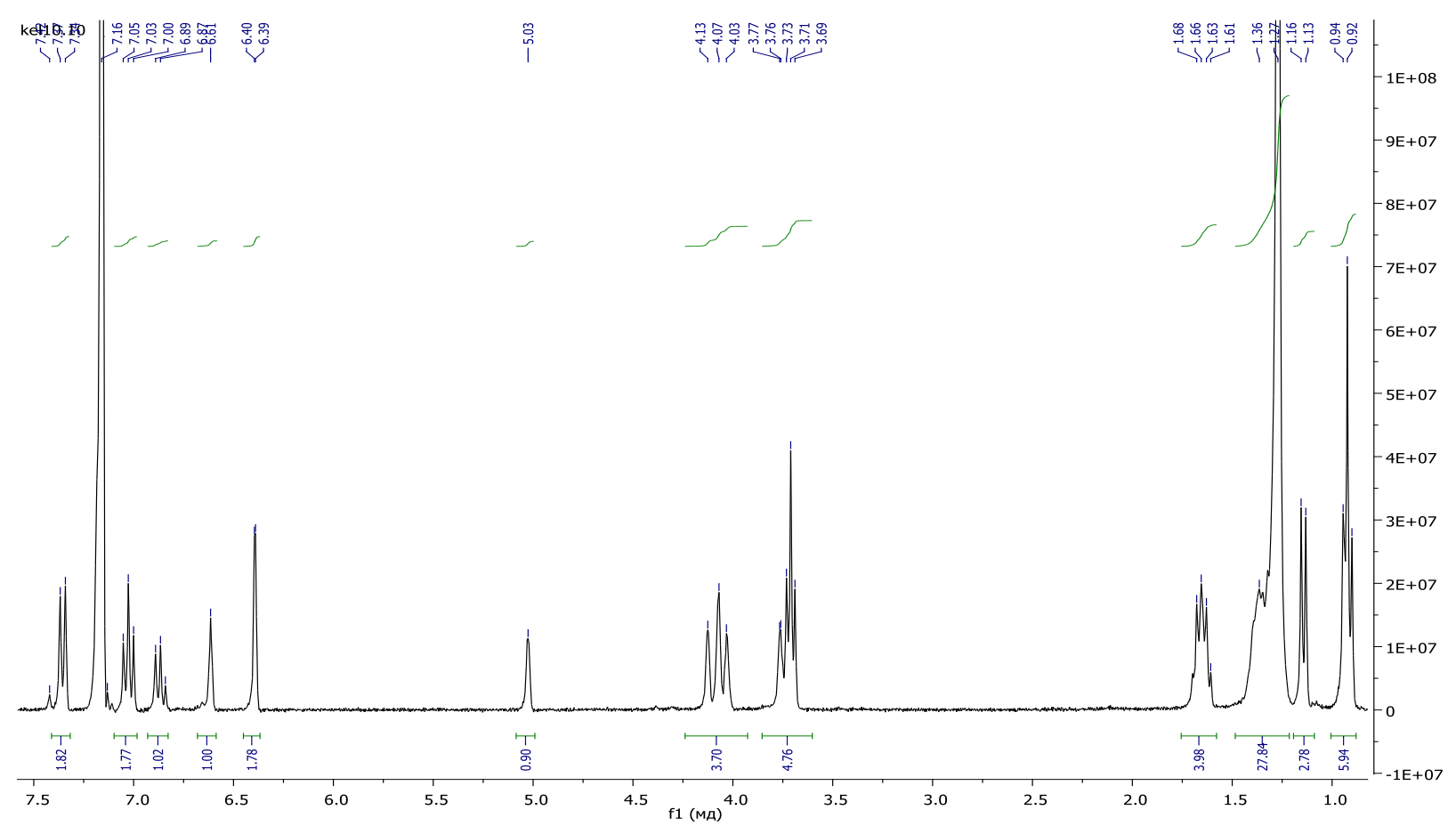

Figure S23. ${ }^{1} \mathrm{H}$ NMR spectra of compound 19 in deuterobenzene. 


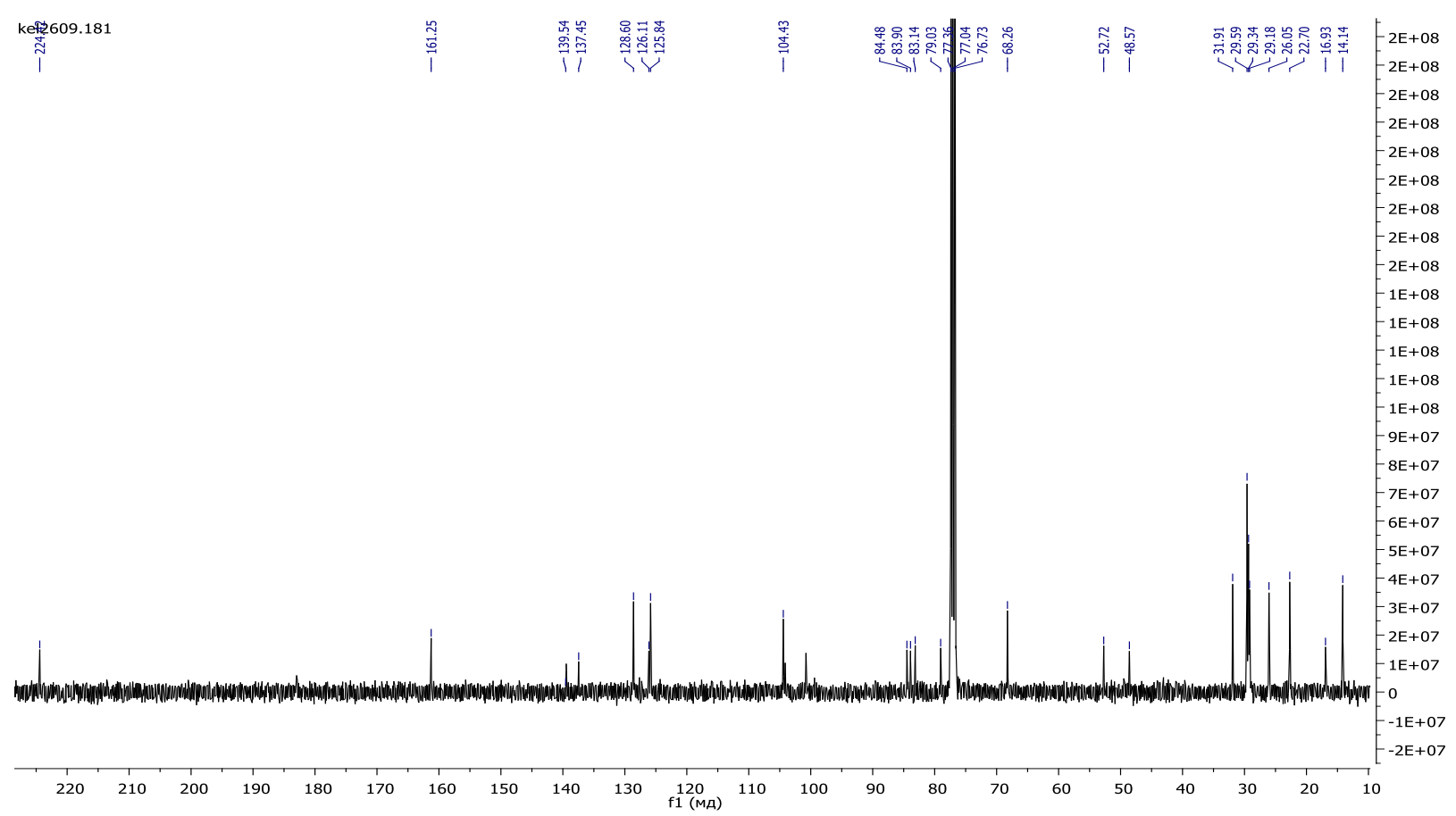

Figure S24. ${ }^{13} \mathrm{C}$ NMR spectra of compound 19 in $\mathrm{CDCl}_{3}$.

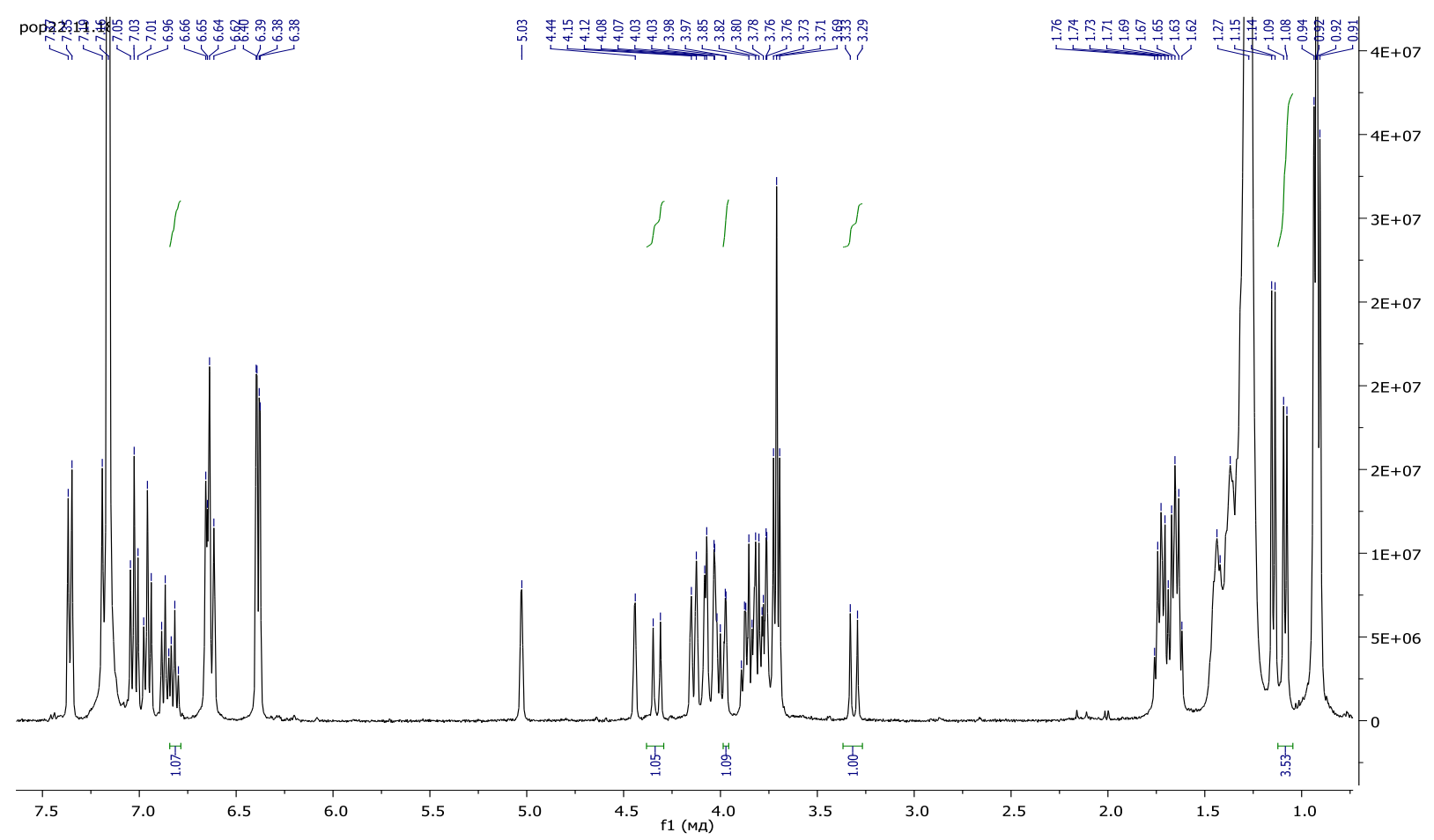

Figure S25. ${ }^{1} \mathrm{H}$ NMR spectra of irradiation of compound $\mathbf{1 9}$ in deuterobenzene for $4 \mathrm{~min}$. 


\section{UV-Vis spectra}

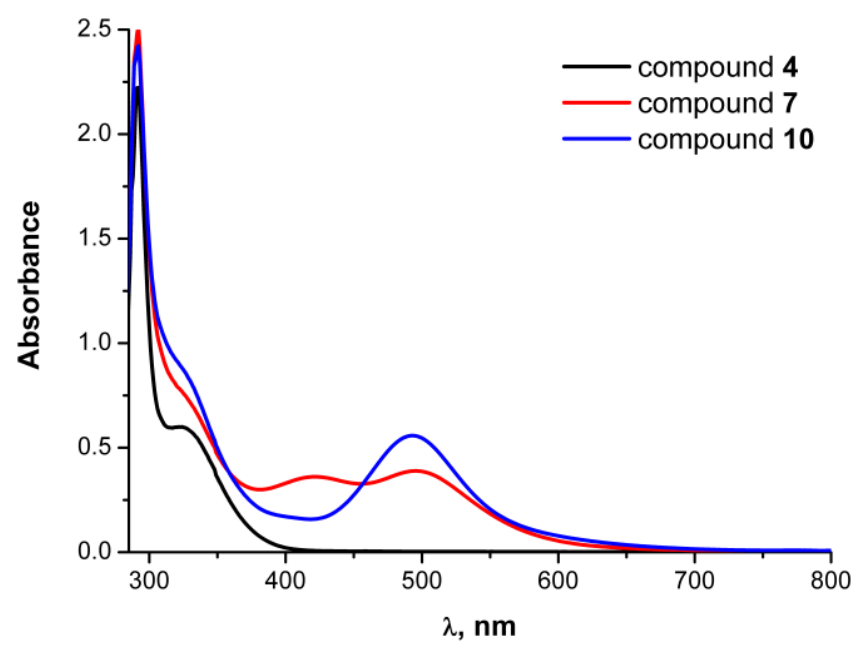

Figure S26. UV-Vis spectra of complex 4, chelate $\mathbf{7}$ and radical $\mathbf{1 0}$ in benzene.

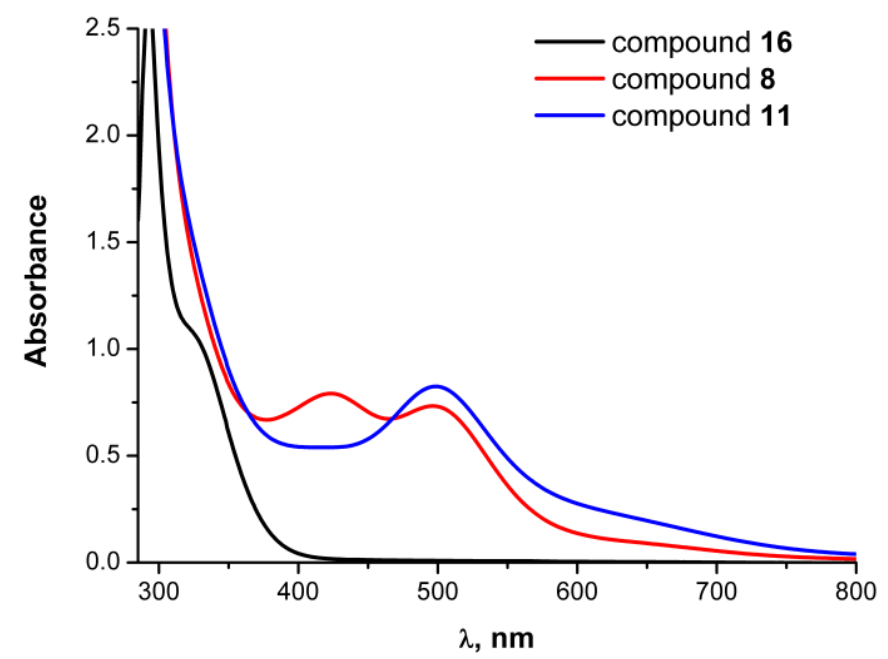

Figure S27. UV-Vis spectra of complex 16, chelate $\mathbf{8}$ and radical 11 in THF.

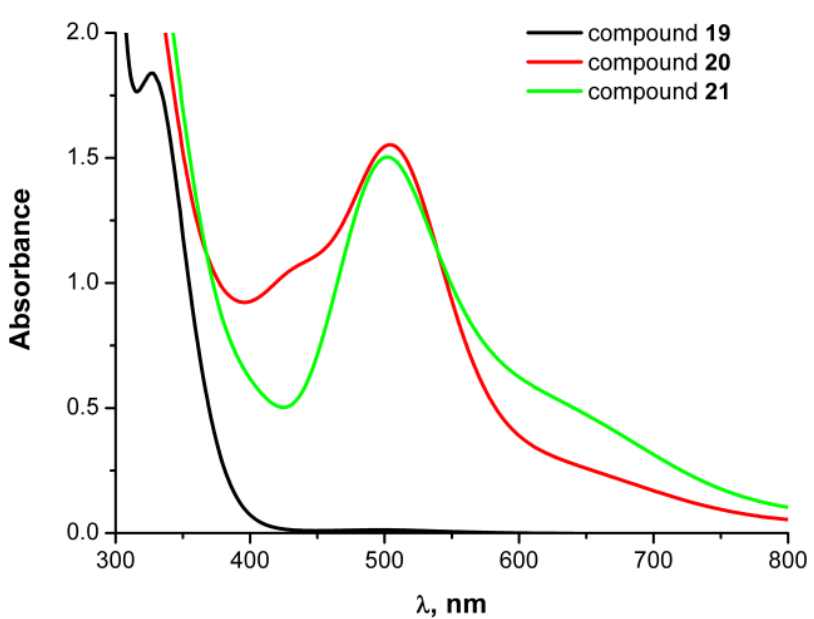

Figure S28. UV-Vis spectra of complex 19, chelate 20 and radical 21 in benzene. 


\section{Mass spectra}

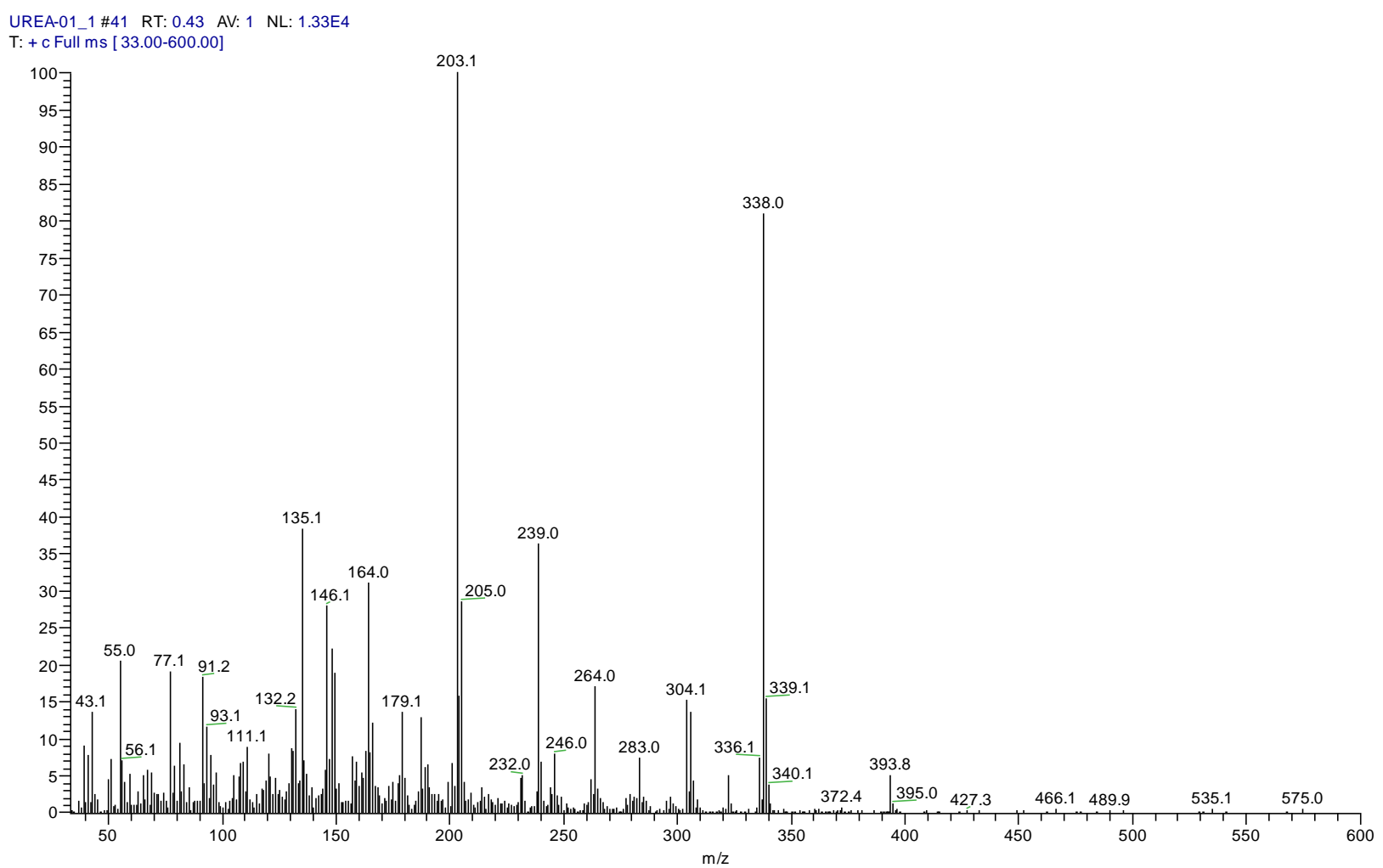

Figure S29. Mass spectrum of compound 6.

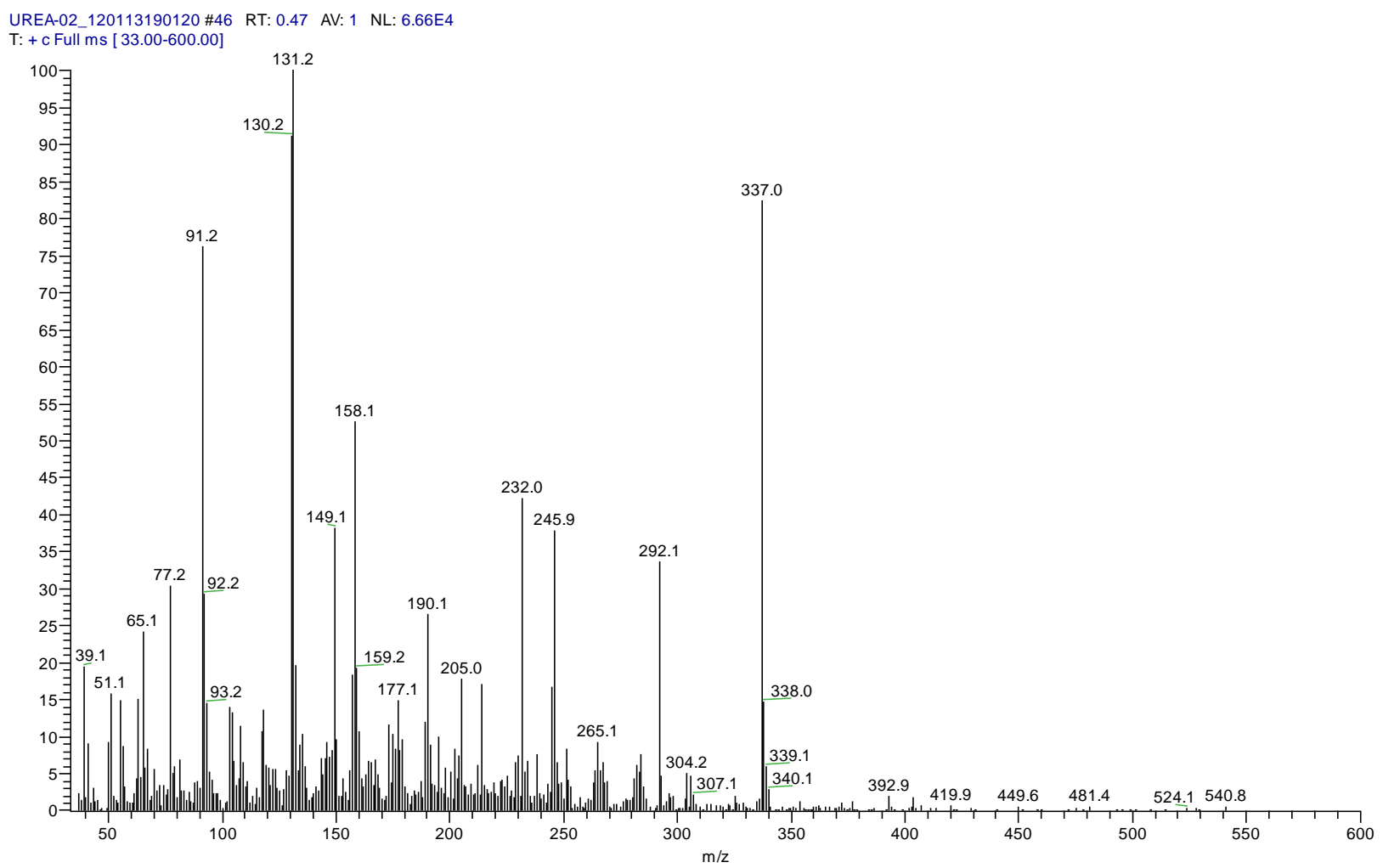

Figure S30. Mass spectrum of compound 12. 


\section{X-ray data}

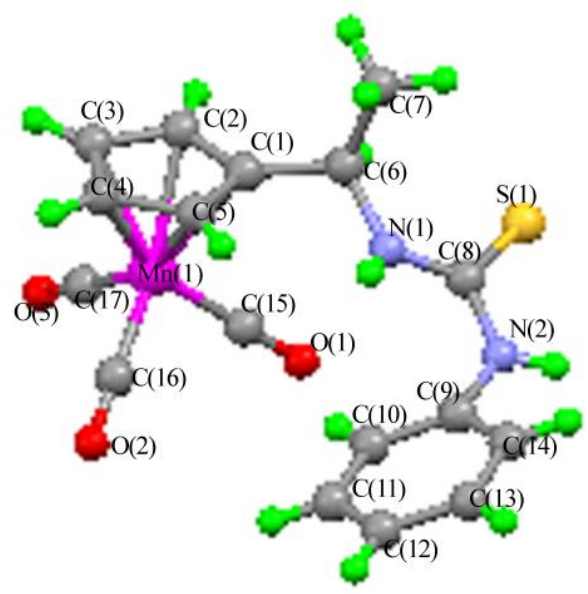

Figure S31. Molecular structure of 4 in the crystal. Selected bond lengths $(\AA)$ : $M n(1)-C(1)$ 2.161, Mn(1)-C(15) 1.801, C(1)-C(6) 1.508, C(6)-N(1) 1.464, N(1)-C(8) 1.344, N(2)-C(8) $1.354, \mathrm{C}(8)-\mathrm{S}(1) 1.698$.

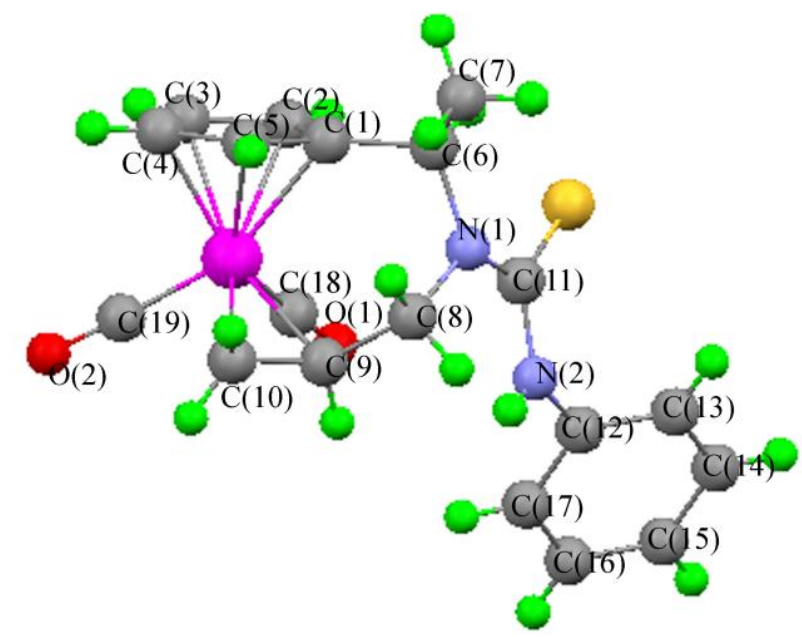

Figure S32. Molecular structure of $\mathbf{1 7}$ in the crystal. Selected bond lengths $(\AA)$ : $\mathrm{Mn}(1)-\mathrm{C}(1)$ 2.160, Mn(1)-C(9) 2.153, Mn(1)-C(10) 2.144, Mn(1)-C(18) 1.791, C(1)-C(6) 1.514, C(6)-N(1) 1.486, N(1)-C(11) 1.357, C(8)-C(9) 1.514, C(9)-C(10) 1.406, N(2)-C(11) 1.355, C(11)-S(1) 1.697.

Table S2. Crystal data, data collection and structure refinement parameters for $\mathbf{4}$ and $\mathbf{1 7 .}$

\begin{tabular}{lll}
\hline Compound & $\mathbf{4}$ & $\mathbf{1 7}$ \\
\hline Molecular formula & $\mathrm{C}_{17} \mathrm{H}_{15} \mathrm{MnN}_{2} \mathrm{O}_{3} \mathrm{~S}$ & $\mathrm{C}_{19} \mathrm{H}_{19} \mathrm{MnN}_{2} \mathrm{O}_{2} \mathrm{~S}$ \\
Formula weight & 382.31 & 394.36 \\
Dimension, mm & $0.48 \times 0.33 \times 0.06$ & $0.28 \times 0.27 \times 0.20$ \\
Temperature, K & $120(2)$ & $100(2)$ \\
Crystal system & monoclinic & orthorhombic \\
Space group & $P 2_{1} / \mathrm{c}$ & $P 2_{1} 2_{1} 2_{1}$ \\
$a, \AA$ & $17.4375(9)$ & $10.2317(4)$ \\
$b, \AA$ & $5.9269(3)$ & $12.9587(5)$
\end{tabular}




\begin{tabular}{lll}
$c, \AA$ & $17.8745(9)$ & $12.9648(5)$ \\
$\alpha$, deg. & 90 & 90 \\
$\beta$, deg. & $115.8810(10)$ & 90 \\
$\gamma$, deg. & 90 & 90 \\
$V, \AA^{3}$ & $1662.05(15)$ & $1719.00(12)$ \\
$Z$ & 4 & 4 \\
$\rho_{\text {calc }}, \mathrm{g} \mathrm{cm}{ }^{-3}$ & 1.528 & 1.524 \\
Linear absorption $(\mu), \mathrm{cm}^{-1}$ & 9.37 & 9.04 \\
$\mathrm{~T}_{\min } / \mathrm{T}_{\text {max }}$ & $0.662 / 0.946$ & $0.714 / 0.956$ \\
$2 \theta_{\text {max }}$, deg. & 60 & 70 \\
No. unique refl. $\left(R_{\text {int }}\right)$ & $19648(0.0222)$ & $20239(0.0347)$ \\
No. observed refl. $(I>2 \sigma(I))$ & 4128 & 3214 \\
No. parameters & 220 & 231 \\
$R_{l}(\text { on } F \text { for observed refl. })^{\mathrm{a}}$ & 0.0239 & 0.0241 \\
$w R_{2}\left(\text { on } F^{2} \text { for all refl. }\right)^{\mathrm{b}}$ & 0.0655 & 0.0637 \\
$G O O F$ & 1.032 & 1.053 \\
\hline${ }^{\mathrm{a}} R_{l}=\Sigma|| F_{o}|-| F_{c}|| / \Sigma\left|F_{o}\right|$ & \\
${ }^{\mathrm{b}} w R_{2}=\left\{\Sigma\left[w\left(F_{o}{ }^{2}-F_{c}{ }^{2}\right)^{2}\right] / \Sigma w\left(F_{o}{ }^{2}\right)^{2}\right\}^{1 / 2}$ & \\
& &
\end{tabular}




\section{Cyclic voltammogram}

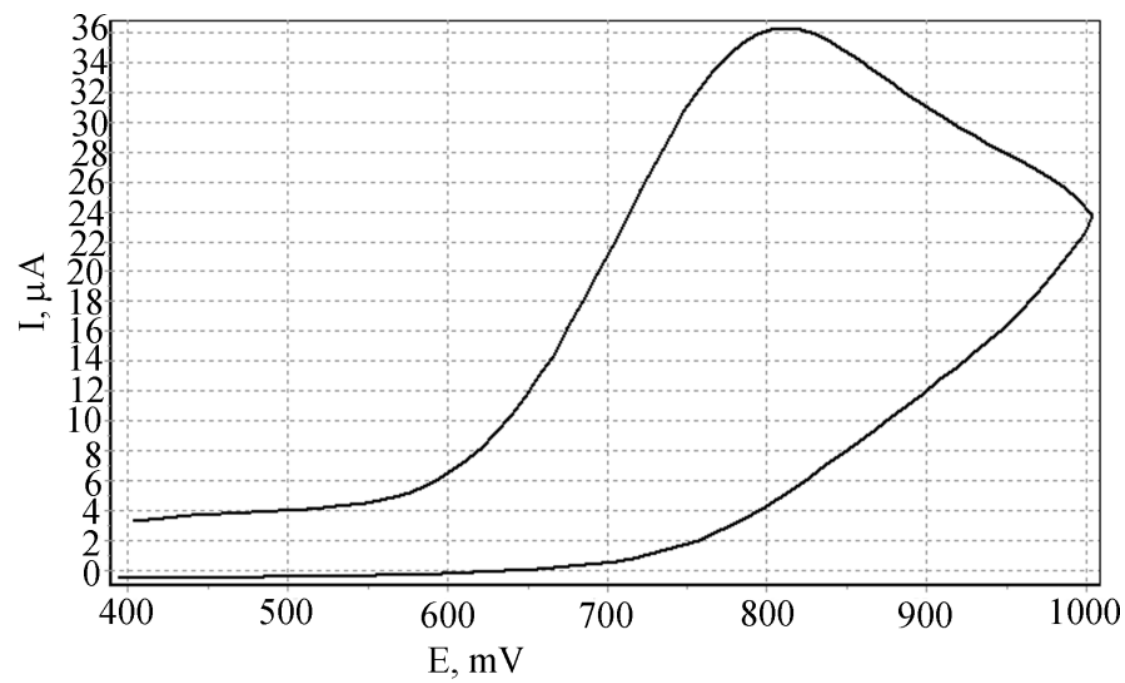

Figure S33. Cyclic voltammogram of $0.1 \mathrm{M}$ solution of tetraethylammonium tetrafluoroborate in acetonitrile in the presence of $7.8 \times 10^{-3} \mathrm{M}$ of $\mathbf{1 2}$. Scan rate $100 \mathrm{mV} / \mathrm{s}$. 


\section{DFT calculation}

Table S3. Calculated characteristics of compounds 4-12, 16 and 17 by methods of B3LYP/6$31 \mathrm{G}^{*}$ and DFT B3LYP/6-311+G*.

\begin{tabular}{|c|c|c|c|c|c|}
\hline Compound & Solvent & $E_{t}$, a.u. & $E_{z p c}$,a.u. & $E_{G}$, a.u. & $\begin{array}{c}S, \text { kcal/M } \\
\text { grad }\end{array}$ \\
\hline 4 & Gas phase & -2541.187597 & -2540.896608 & -2540.953681 & 171.226 \\
\hline 7 & Gas phase & $\begin{array}{c}-2427.832853 \\
(-2428.164952)\end{array}$ & -2427.550599 & -2427.601680 & 152.818 \\
\hline $7 \mathbf{a}$ & Gas phase & $\begin{array}{c}-2427.820918 \\
(-2428.145070)\end{array}$ & -2427.541802 & -2427.591677 & 150.497 \\
\hline 10 & Gas phase & -2427.232189 & -2426.962317 & -2427.013718 & 152.908 \\
\hline 5 & Gas phase & -2618.578086 & -2618.253118 & -2618.313312 & 181.632 \\
\hline 8 & Gas phase & $\begin{array}{c}-2505.221343 \\
(-2505.568263) \\
\end{array}$ & -2504.904920 & -2504.958187 & 161.266 \\
\hline $8 \mathbf{a}$ & Gas phase & $\begin{array}{c}-2505.202944 \\
(-2505.5433701)\end{array}$ & -2504.890266 & -2504.942990 & 160.518 \\
\hline 11 & Gas phase & -2504.615067 & -2504.312257 & -2504.367703 & 166.439 \\
\hline 16 & Gas phase & $\begin{array}{c}-2505.224749 \\
(-2505.562081)\end{array}$ & -2504.906749 & -2504.959319 & 158.147 \\
\hline \multirow[t]{4}{*}{6} & Gas phase & -2657.884890 & -2657.531620 & -2657.592041 & 184.981 \\
\hline & Benzene & -2657.891746 & -2657.538565 & -2657.599123 & 185.279 \\
\hline & THF & -2657.898198 & -2657.545111 & -2657.605385 & 184.637 \\
\hline & $\mathrm{CH}_{3} \mathrm{CN}$ & -2657.901499 & -2657.548509 & -2657.608796 & 184.726 \\
\hline \multirow[t]{4}{*}{9} & Gas phase & $\begin{array}{c}-2544.531895 \\
(-2544.886055)\end{array}$ & -2544.187233 & -2544.241569 & 166.386 \\
\hline & Benzene & -2544.539787 & -2544.195039 & -2544.249146 & 165.790 \\
\hline & THF & -2544.546894 & -2544.202258 & -2544.256582 & 166.307 \\
\hline & $\mathrm{CH}_{3} \mathrm{CN}$ & -2544.550402 & -2544.205924 & -2544.260765 & 167.526 \\
\hline \multirow[t]{4}{*}{ 9a } & Gas phase & $\begin{array}{c}-2544.515367 \\
(-2544.862845)\end{array}$ & -2544.174422 & -2544.228122 & 165.452 \\
\hline & Benzene & -2544.521434 & -2544.180421 & -2544.233778 & 164.556 \\
\hline & THF & -2544.526796 & -2544.185827 & -2544.239211 & 164.568 \\
\hline & $\mathrm{CH}_{3} \mathrm{CN}$ & -2544.529361 & -2544.188464 & -2544.242013 & 164.952 \\
\hline \multirow[t]{4}{*}{12} & Gas phase & -2543.926207 & -2543.595061 & -2543.651203 & 170.644 \\
\hline & Benzene & -2543.931937 & -2543.600914 & -2543.657095 & 170.715 \\
\hline & THF & -2543.937768 & -2543.606832 & -2543.663177 & 171.096 \\
\hline & $\mathrm{CH}_{3} \mathrm{CN}$ & -2543.940885 & -2543.609967 & -2543.666265 & 170.994 \\
\hline \multirow[t]{4}{*}{17} & Gas phase & $\begin{array}{c}-2544.537829 \\
(-2544.882400)\end{array}$ & -2544.191470 & -2544.245021 & 163.076 \\
\hline & Benzene & -2544.545229 & -2544.198834 & -2544.252116 & 162.451 \\
\hline & THF & -2544.552466 & -2544.206133 & -2544.259507 & 162.685 \\
\hline & $\mathrm{CH}_{3} \mathrm{CN}$ & -2544.556194 & -2544.210029 & -2544.263797 & 163.646 \\
\hline
\end{tabular}




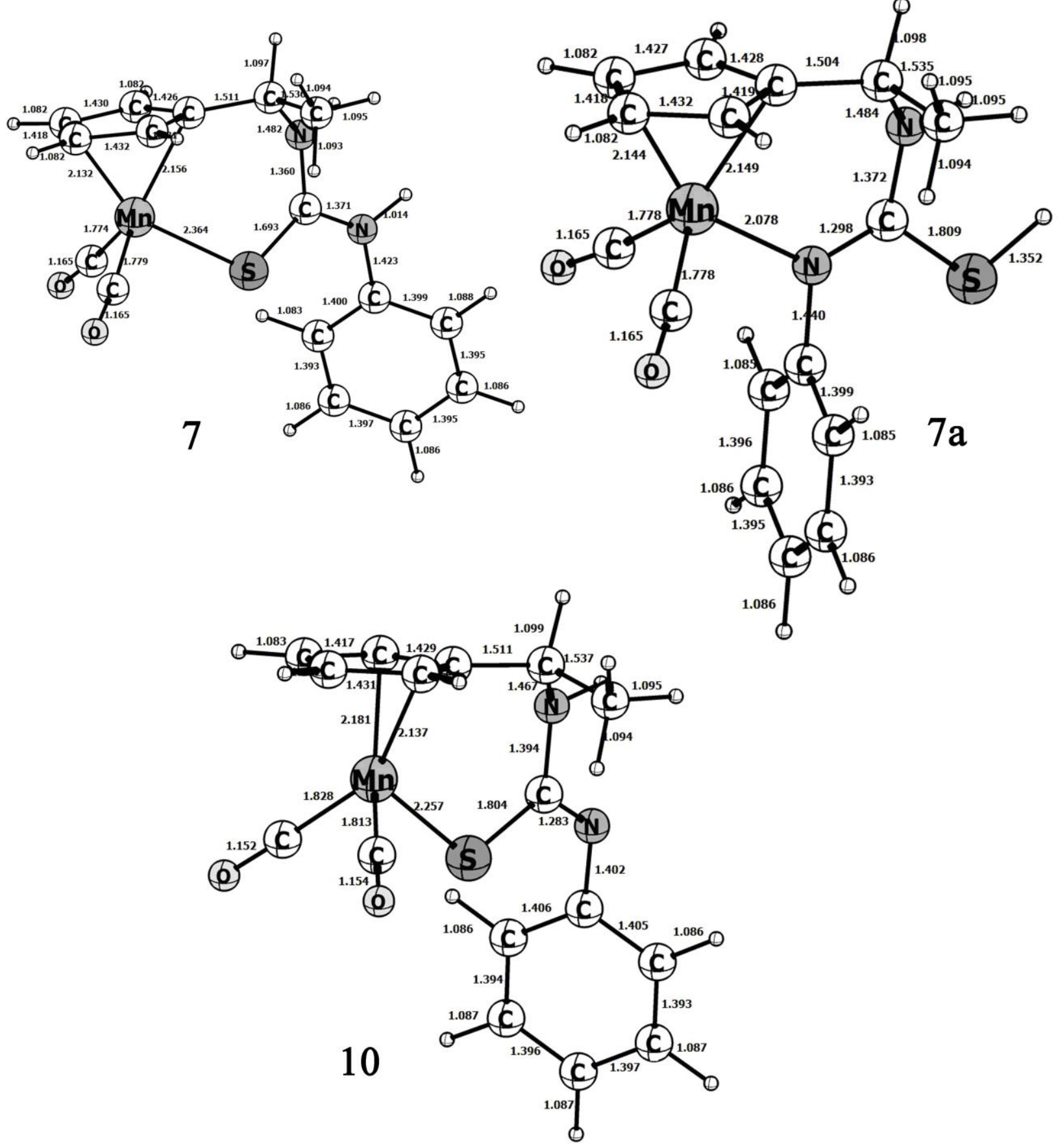

Figure S34. Optimized structures of compounds 7, 7a and 10. 

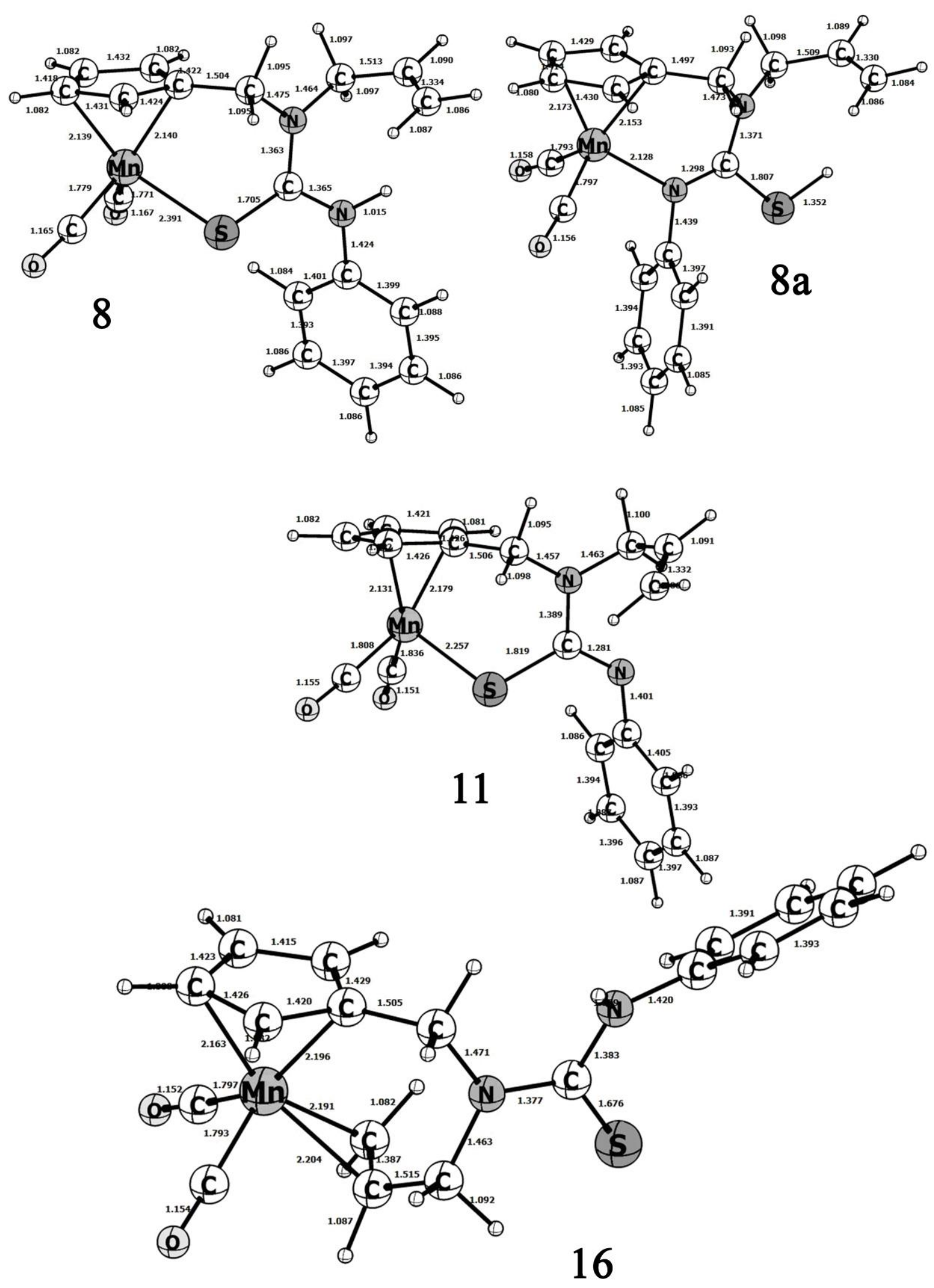

Figure S35. Optimized structures of compounds 8, 8a, 11 and 16. 

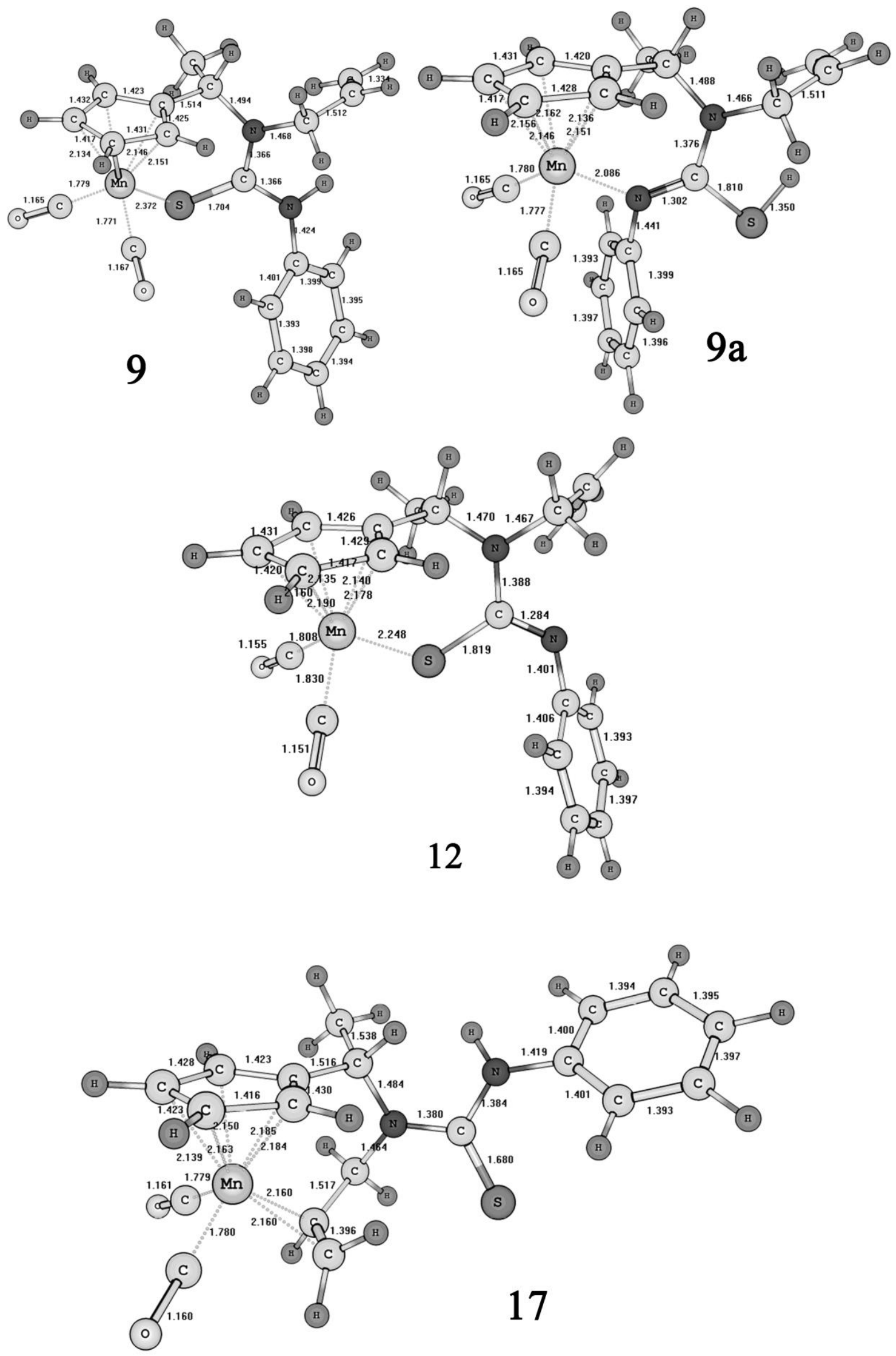

Figure S36. Optimized structures of compounds 9, 9a, 12 and 17. 
Table S4. The dependence of the atomic spin population $(\sigma)$ in radical 12 on the solvent dielectric constant $(\varepsilon)$.

\begin{tabular}{|l|l|l|l|l|l|}
\hline Solvent & $\varepsilon$ & \multicolumn{2}{|l|}{ DFT (ROB3LYP/6-31G*) } & \multicolumn{2}{l|}{$\begin{array}{l}\text { DFT (ROB3LYP/6- } \\
\left.311+G^{*}\right)\end{array}$} \\
\hline & $(\mathrm{S})$ & $\sigma(\mathrm{Mn})$ & $\sigma(\mathrm{S})$ & $\sigma(\mathrm{Mn})$ & $\sigma(\mathrm{S})$ \\
\hline gas phase & 1.0000 & 0.720 & 0.145 & 0.683 & 0.185 \\
\hline benzene & 2.2706 & 0.731 & 0.134 & 0.696 & 0.172 \\
\hline THF & 7.4257 & 0.743 & 0.121 & 0.711 & 0.156 \\
\hline acetonitrile & 35.6880 & 0.750 & 0.114 & 0.720 & 0.147 \\
\hline
\end{tabular}

